\title{
Racially Based Jury Nullification: Black Power in the Criminal Justice System
}

\author{
Paul Butler ${ }^{\dagger}$
}

Wonders do not confuse. We call them that And close the matter there. But common things surprise us. They accept the names we give with calm, and keep them. Easy-breathing then We brave our next small business. Well, behind Our backs they alter. How were we to know. ${ }^{1}$

Gwendolyn Brooks

$$
* * *
$$

[T] he time that we're living in now . . . is not an era where one who is oppressed is looking toward the oppressor to give him some system or form of logic or reason. What is logical to the oppressor isn't logical to the oppressed. And what is reason to the oppressor isn't reason to the oppressed. The black people in this country are beginning to realize that what sounds reasonable to those who exploit us doesn't sound reasonable to us. There just has to be a new system of reason and logic devised by us who are at the bottom, if we want to get some results in this struggle that is called "the Negro revolution."2

Malcolm X

$\dagger$ Associate Professor of Law, George Washington University Law School. This Essay was supported by a research grant from Dean Jack Friedenthal of George Washington University Law School. It was presented as a work-in-progress at the Mid-Atlantic People of Color Legal Scholarship Conference and before the junior faculty at George Washington. In addition to the participants in those meetings, the author thanks Burlette Carter, Robert Cottrol, Jayne Jerkins, Steven Kim, William Rubenstein, Katheryn Russell, Mark Srere, Carol Steiker, and Robert Tuttle. This Essay is dedicated to Legertha Butler Walton, the author's mother. She is the reason that he is a law professor, hoping to salvage the lives of some desperate people, and not one of those desperate people.

1. GWendolyn Brooks, The Artists' and Models' Ball, in The BeAn EATERs 67, 67 (1960).

2. Malcolm X, Speech at the Leverett House Forum of March 18, 1964, in THE SPEECHES OF MalColm X at HaRVARd 131, 133 (Archie Epps ed., 1968). 


\section{INTRODUCTION}

I was a Special Assistant United States Attorney in the District of Columbia in 1990. I prosecuted people accused of misdemeanor crimes, mainly the drug and gun cases that overwhelm the local courts of most American cities. ${ }^{3}$ As a federal prosecutor, I represented the United States of America and used that power to put people, mainly African-American men, in prison. I am also an African-American man. While at the U.S. Attorney's office, I made two discoveries that profoundly changed the way I viewed my work as a prosecutor and my responsibilities as a black person.

The first discovery occurred during a training session for new Assistants conducted by experienced prosecutors. We rookies were informed that we would lose many of our cases, despite having persuaded a jury beyond a reasonable doubt that the defendant was guilty. We would lose because some black jurors would refuse to convict black defendants who they knew were guilty.

The second discovery was related to the first, but was even more unsettling. It occurred during the trial of Marion Barry, then the second-term mayor of the District of Columbia. Barry was being prosecuted by my office for drug possession and perjury. I learned, to my surprise, that some of my fellow African-American prosecutors hoped that the mayor would be acquitted, despite the fact that he was obviously guilty of at least one of the charges-he had smoked cocaine on FBI videotape. ${ }^{4}$ These black prosecutors wanted their office to lose its case because they believed that the prosecution of Barry was racist.

Federal prosecutors in the nation's capital hear many rumors about prominent officials engaging in illegal conduct, including drug use. Some African-American prosecutors wondered why, of all those people, the government chose to "set up" the most famous black politician in Washington, D.C. They also asked themselves why, if crack is so dangerous, the FBI had allowed the mayor to smoke it. Some members of the predominantly black jury must have had similar concerns: They convicted the mayor of only one count of a fourteen-count indictment, despite the trial judge's assessment that he had “"never seen a stronger government case." Some African-American prosecutors thought that the jury, in rendering its verdict, jabbed its black

3. See Joseph Calve, On Golden Hill; A "Typical" Day in Urban G.A., CoNN. L. TRIB., Oct. 24, 1994, at 1; Michael D. Hinds, Administration Pushes Gun-Related Cases on Federal Courts, CHI. DAILY L. Bull., May 17, 1991, at 3.

4. See George Hackett \& Bob Cohn, Mayor Barry: Lurid Tales of the Tape, NewsweEk, July 9, 1990, at 25 .

5. See infra Section I.A for a description of the investigation and prosecution of Barry.

6. Christopher B. Daly, Barry Judge Castigates Four Jurors; Evidence of Guilt was "Ovenwhelming," Jackson Tells Forum, WASH. PoST, Oct. 31, 1990, at A1 (quoting U.S. District Judge Thomas Penfield Jackson). The trial judge's comments were made after the verdict. 
thumb in the face of a racist prosecution, and that idea made those prosecutors glad.

As such reactions suggest, lawyers and judges increasingly perceive that some African-American jurors vote to acquit black defendants for racial reasons, ${ }^{7}$ a decision sometimes expressed as the juror's desire not to send yet another black man to jail. ${ }^{8}$ This Essay examines the question of what role race should play in black jurors' decisions to acquit defendants in criminal cases. Specifically, I consider trials that include both African-American defendants and African-American jurors. I argue that the race of a black defendant is sometimes a legally and morally appropriate factor for jurors to consider in reaching a verdict of not guilty or for an individual juror to consider in refusing to vote for conviction. ${ }^{9}$

My thesis is that, for pragmatic and political reasons, the black community is better off when some nonviolent lawbreakers remain in the community rather than go to prison. The decision as to what kind of conduct by AfricanAmericans ought to be punished is better made by African-Americans themselves, based on the costs and benefits to their community, than by the traditional criminal justice process, which is controlled by white lawmakers and white law enforcers. Legally, the doctrine of jury nullification gives the power to make this decision to African-American jurors who sit in judgment of African-American defendants. Considering the costs of law enforcement to the black community and the failure of white lawmakers to devise significant nonincarcerative responses to black antisocial conduct, it is the moral responsibility of black jurors to emancipate some guilty black outlaws.

Part I of this Essay describes two criminal cases in the District of Columbia in which judges feared that defendants or their lawyers were sending race-conscious, "forbidden" messages to black jurors and attempted to regulate those messages. I suggest that the judicial and public responses to those cases signal a dangerous reluctance among many Americans to engage in meaningful discourse about the relationship between race and crime. In Part II, I describe racial critiques of the criminal justice system. I then examine the evolution of

7. Cf. Mark Curriden, Blowing Smoke, A.B.A. J., Oct. 1995, at 56, 59 ("As in the Simpson case, race has become the most popular way of setting an underlying tone to grab the sympathy of black jurors and possibly the guilt of white jurors, say judges and lawyers.").

8. See, e.g., Barton Gellman \& Sari Horwitz, Letter Stirs Debate After Acquittal; Writer Says Jurors Bowed to Racial Issue in D.C. Murder Case, WASH. POST, Apr. 22, 1990, at A1 (quoting letter to court from anonymous juror following acquittal in murder case saying that "most of the jury believed [the defendant] was guilty, but bowed to holdouts who 'didn't want to send anymore Young Black Men to Jail"'). But cf. Dan Snodderly, When 12 Strangers Came Together, WASH. PoST, May 10, 1994, at A16 (reporting experience of letter-to-editor writer on jury where several jurors held "concern that so many young black men were in prison and that the judicial system did not seem fair to young blacks ... . but no one argued for acquittal on that basis").

9. An acquittal on this basis would be jury nullification. Although most American jurisdictions require a unanimous verdict, and a single juror's vote for acquittal would not itself free the defendant, such a vote would prevent conviction. The prosecution would then have the option of either retrying the case or dismissing it. 
the doctrine of jury nullification and suggest, in light of this doctrine, that racial considerations by African-American jurors are legally and morally right. Part III proposes a framework for analysis of the kind of criminal cases involving black defendants in which jury nullification is appropriate, and considers some of the concerns that implementation of the proposal raises.

My goal is the subversion of American criminal justice, at least as it now exists. Through jury nullification, I want to dismantle the master's house with the master's tools. ${ }^{10} \mathrm{My}$ intent, however, is not purely destructive; this project is also constructive, because I hope that the destruction of the status quo will not lead to anarchy, but rather to the implementation of certain noncriminal ways of addressing antisocial conduct. Criminal conduct among AfricanAmericans is often a predictable reaction to oppression. Sometimes black crime is a symptom of internalized white supremacy; other times it is a reasonable response to the racial and economic subordination every African-American faces every day. Punishing black people for the fruits of racism is wrong if that punishment is premised on the idea that it is the black criminal's "just deserts." Hence, the new paradigm of justice that I suggest in Part III rejects punishment for the sake of retribution and endorses it, with qualifications, for the ends of deterrence and incapacitation.

In a sense, this Essay simply may argue for the return of rehabilitation as the purpose of American criminal justice, but a rehabilitation that begins with the white-supremacist beliefs that poison the minds of us all-you, me, and the black criminal. I wish that black people had the power to end racial oppression right now. African-Americans can prevent the application of one particularly destructive instrument of white supremacy-American criminal justice-to some African-American people, and this they can do immediately. I hope that this Essay makes the case for why and how they should. ${ }^{11}$

10. I borrow-and corrupt-this phrase from AUDRE LORDE, SISTER OUTSIDER 110 (1984). My use is a corruption because Lorde states that the master's tools can "never" dismantle the master's house. I explain my belief that the thoughtful use of jury nullification is morally right for African-Americans below in Section II.C.

11. Both historically and recently, jury nullification has been associated with individuals and groups that have objectives quite contrary to mine, which are black self-help and self-determination. See, e.g., Wade Lambert, More Angry Men: Militias Are Joining Jury-Power Activists to Fight Government; Tax Protesters, Survivalists Benefit from Message: Juries Can Ignore Law; "Red" Beckman's Revenge, WALL ST. J., May 25, 1995, at Al (describing advocacy of jury nullification by members of extremist groups that support militia and white-supremacist movements). Although some of these right-wing advocates and I share a dissatisfaction with American democracy as an effective protector of the rights of unpopular minorities, I do not think that the use of jury nullification by these groups has the same moral legitimacy as its use by African-Americans. I make the moral case for African-Americans based on the racial bias of the criminal justice system infra Section II.C. Legally, however, nullification is as much the prerogative of white supremacists as of other jurors, including African-Americans. The fact that some would use nullification to undermine justice for African-Americans is hardly a reason, as some might argue, for blacks not to use nullification to advance justice.

Perhaps the fallacy of that argument can best be appreciated by examining it in the related context of electoral politics. Many white people use their votes at the ballot box to achieve the same goal as rightwing advocates of jury nullification: black subordination. That fact is not usually offered as evidence that African-Americans should not exercise their legal right to vote, and to vote in their own interests. The way 


\section{SeCret MEsSages Everyone Hears}

Americans seem reluctant to have an open conversation about the relationship between race and crime. Lawmakers ignore the issue, judges run from it, and crafty defense lawyers exploit it. It is not surprising, then, that some African-American jurors are forced to sneak through the back door what is not allowed to come in through the front: the idea that "race matters" in criminal justice. ${ }^{12}$ In this part, I tell two stories about attempts by defense attorneys to encourage black jurors' sympathy for their clients, and then I examine how these attempts provoked many people to act as though the idea of racial identification with black defendants was ridiculous or insulting to black people. In fact, the defense attorneys may well have been attempting to encourage black jurors' sympathy as part of their trial strategies. The lesson of the stories is that the failure of the law to address openly the relationship between race and crime fosters a willful and unhelpful blindness in many who really ought to see and allows jury nullification to go on without a principled framework. This Essay offers such a framework and encourages nullification for the purpose of black self-help.

\section{A. United States v. Marion Barry}

The time is January 1990. The mayor of the District of Columbia is an African-American man named Marion Barry. African-Americans make up approximately sixty-six percent of the population of the city. ${ }^{13}$ The mayor is so popular in the black community that one local newspaper columnist has dubbed him "Mayor for Life."14 Barry is hounded, however, by rumors of his

that some white people choose to exercise their power to vote-at the ballot box or in the jury box-is irrelevant to how black people should exercise that same power. Indeed, some commentators have noted a disturbing double standard in the analysis of the appropriateness of nullification, depending upon which group is engaging in it. See, e.g., Curriden, supra note 7, at 59 ("Nobody cared . . . [when] for 200 years, white people got off on criminal charges [in violent crimes against blacks by] raising the issue of race and seeking jury nullification. These people only started caring when black people started doing the same thing to get off." (quoting New York City lawyer and political activist Ronald Kuby)). While I think that Kuby overstates the case-many liberals did care about jury nullification by Southern whites in cases of violent crimes against blacks-I am also concerned about the racial implications of recent critiques of jury nullification.

12. The phrase is taken from CORNELL WEST, RACE MATTERS (1993). Lani Guinier has expressed the view that blacks and whites are unable to engage in open discussion with each other about race. See Dale Russakoff, Lani Guinier Is Still Alive and Talking, WASH. POST, Dec. 12, 1993, Magazine, at W14, W16, W32.

13. See U.S. DEP'T OF COMMERCE, ECONOMICS \& STATISTICS ADMIN., BUREAU OF THE CENSUS, STATISTICAL ABSTRACT OF THE UNITED STATES 1994, at 46 (1994) [hereinafter STATISTICAL ABSTRACT 1994].

14. See Jefferson Morley, Jack the Ripper; Haunted by Respectability, the City Paper Editor Skips Town, WASH. POST, Feb. 12, 1995, at C5. 
using drugs and "chasing women." that they are racist. ${ }^{16}$

On January 18, 1990, the mayor is contacted by an old friend, Rasheeda Moore, who tells him that she is visiting for a short time, and staying at a local hotel. ${ }^{17}$ The mayor stops by later that afternoon and telephones Ms. Moore's room from the lobby of the hotel. He wants her to come downstairs to the lobby for a drink, but she requests that he come up to her room. The mayor assents, joins Ms. Moore in the room, and the two converse. At some point, Ms. Moore produces crack cocaine and a pipe, and invites the mayor to smoke it. He first demurs, then consents, and after he inhales smoke from the pipe, agents of the FBI and the Metropolitan Police Department storm the room. It turns out that Ms. Moore is a government informant, and the police have observed and videotaped the entire proceeding in the hotel room. The mayor is arrested and subsequently charged with one count of conspiracy to possess cocaine, ten counts of possession of cocaine, and three counts of perjury for allegedly lying to the grand jury that had investigated him. ${ }^{18}$ The mayor publicly asserts that he is the victim of a racist prosecution. ${ }^{19}$

It is the last week in June 1990. The mayor is on trial in federal court. ${ }^{20}$ The judge is white. Of the twelve jurors, ten are African-American. ${ }^{21}$ Rasheeda Moore, the government's star witness, is expected to testify. The mayor has four passes to give to guests he would like to attend his trial. On this day, he has given one pass to Minister Louis Farrakhan, the controversial leader of the Nation of Islam. Farrakhan has publicly supported Barry since his arrest, in part by suggesting that the sting operation and the prosecution were racist. ${ }^{22}$ When Farrakhan attempts to walk into the courtroom, a U.S. deputy marshal bars his entry. When Barry's attorney protests, the judge states, outside of the jury's hearing, that Farrakhan's "'presence would be potentially

15. See Bella Stumbo, Mayor Barry: Keeping D.C. Guessing, L.A. TMES, Jan. 7, 1990, at A1, A20.

16. See id.

17. The following account is drawn from Michael York, Excerpts from Videotape of Barry's Arrest at the Vista Hotel, WASH. POST, June 29, 1990, at A22.

18. See United States v. Barry, 938 F.2d 1327, 1329 (D.C. Cir. 1991). Because the District of Columbia is a federal "territory," see D.C. CODE ANN. \$1-101 (1995), most crimes are prosecuted by the United States Attorney, who, at the time of the Barry prosecution, and like every District of Columbia chief prosecutor before him, was white, $c f$. Jim Clardy, New Faces Approach Federal Bench, WASH. TimES, Oct. 4, 1993, at C4 (reporting appointment of first black U.S. Attorney for Washington, D.C.).

19. See Mary McGrory, Barry Putting His Trial on Trial, WASH. POST, July 3, 1990, at A2. Barry's lawyer made a similar claim in describing the defense strategy. See Michael Hedges, Mundy to Stress "GetBarry" Zeal, WASH. TIMES, July 4, 1990, at A1.

20. The trial decision can be found at United States v. Barry, No. 90-0068, 1990 WL 174907 (D.D.C. Oct. 26, 1990), aff'd, 938 F.2d 1327 (D.C. Cir. 1991).

21. See Steve Twomey \& DeNeen L. Brown, Barry Guilty on 1 Count, Cleared on I; Mistrial Declared on 12 Other Charges; Panel Split 6 to 6 On Vista Charge, One Juror Says, WASH. PosT, Aug. 11,1990 , at $\mathrm{Al}, \mathrm{A} 13$.

22. See Nathan McCall, Farrakhan Barred from Barry Trial; Muslim Leader "Persona Non Grata," Judge Says, WASH. POST, June 29, 1990, at C1, C4. 
disruptive, very likely intimidating, and he is a persona non grata for the [rest] of this case." ${ }^{23}$ Rasheeda Moore then takes the stand.

The next day, the Reverend George Stallings appears at the trial with one of Barry's guest passes in hand. Stallings is a black Roman Catholic priest who, the previous year, received extensive publicity when he accused the Catholic Church of being hopelessly racist, left it, and founded his own church. ${ }^{24}$ When Stallings reaches the courtroom, the deputy marshal, following the instructions of the judge, does not let him enter. The judge explains, again outside of the jury's hearing, that Stallings is "'in my judgment, not an ordinary member of the public and his presence would very likely have the same effect as Mr. Farrakhan's." 25 The judge also indicates that there are "“others who fit the same category." 26 Barry's attorney asks for a list of those persons. The judge replies, "I think you will know them when you see them."'27

In the wake of these two episodes, the American Civil Liberties Union, representing Barry, Farrakhan, and Stallings, files an emergency appeal of the trial judge's decision. It argues that the judge's refusal to allow Barry's guests to attend the trial violated Barry's Sixth Amendment right to a fair trial and the First Amendment rights of the guests. ${ }^{28}$ In response, the judge's attorneys state that the judge excluded Farrakhan and Stallings because their presence in the courtroom would send an "impermissible message" of "intimidation" and "racial animosity" to jurors and witnesses. ${ }^{29}$ The judge's attorneys argue that the excluded persons' views of the prosecution had been highly publicized and that their appearance at the trial was consistent with Barry's "spublicly avowed strategies of seeking a hung jury and jury nullification." "30 The judge's attorneys argue that Farrakhan and Stallings attended the trial " "not to view the proceedings or to show generalized concern, but instead to send a forbidden message to the jury and witness." $" 31$

The U.S. Court of Appeals for the District of Columbia Circuit rules that Farrakhan and Stallings should have presented their constitutional claims to the trial judge prior to seeking relief in the appellate court. ${ }^{32}$ Accordingly, it remands the case back to the trial judge. Because the trial has been halted

23. Saundra Torry, Stallings Excluded From Barry Trial; ACLU to Appeal Judge's Actions Barring Bishop, Farrakhan, WASH. POST, June 30, 1990, at A13.

24. See Lyndsay Griftiths, Judge Bars Two Blacks from Barry Trial, Opening New Legal Case, Reuters, July 3, 1990, available in LEXIS, News Library, Wires File; Saundra Torry, Judge Ordered to Defend Barring Farrakhan, Stallings From Trial, WASH. POST, July 3, 1990, at A12.

25. Torry, supra note 23 , at A13.

26. Id.

27. Id.

28. Torry, supra note 24 , at A12.

29. Saundra Torry, Court Hears Defense of Judge's Bans, WASH. POST, July 4, 1990, at A1, A12.

30. Id.

31. Id.

32. United States v. Barry, Nos. 90-3150, 90-3149, \& 90-3151, 1990 WL 104925 (D.C. Cir. July 5, 1990). 
pending appeal, however, the D.C. Circuit, in light of the "exigent circumstances," lists several "pertinent considerations" for the trial judge on remand. ${ }^{33}$ The considerations mainly concern the judge's power to regulate the attendance of those who threaten physically to disrupt a courtroom. ${ }^{34}$ The court does note, though, that:

No individual can be wholly excluded from the courtroom merely because he advocates a particular political, legal or religious point of view-even a point of view that the district court or we may regard as antithetical to the fair administration of justice. Nor can an individual be wholly excluded from the courtroom because his presence is thought to send an undesirable message to the jurors except that of physical intimidation. ${ }^{35}$

The trial judge hears the message of the court of appeals. In lieu of resolving Farrakhan and Stallings's constitutional claims, he instead seeks assurances from their attorneys that their clients know how to conduct themselves in a courtroom. ${ }^{36}$ Indeed, the judge provides the attorneys with his own "special rules" of decorum regarding the trial, stating that "any attempt to communicate with a juror may be punished as criminal contempt of court. ${ }^{37}$ Farrakhan and Stallings's attorneys assure the court that their clients will act with decorum in the courtroom. ${ }^{38}$ The trial continues. The mayor is eventually convicted of one of the indictment's fourteen counts (for perjury), but not of the count in which he smoked the cocaine on videotape. ${ }^{39}$

\section{B. The Attorney Who Wore Kente Cloth}

It is now June 11, 1992. John T. Harvey, III is an African-American criminal defense attorney who practices in the District of Columbia. Harvey represents a black man who is charged with assault with intent to murder. The

33. Id. at $* 1$.

34. The pertinent considerations are as follows:

First, the district court has discretion in governing proceedings within the courtroom to prevent both physical intimidation of participants and disruption of the trial. ... Second, the district court may exercise its discretion to protect particular witnesses from intimidation or harassment while testifying. ... Third, there is no doubt that the district court may exclude an individual who causes a disturbance in the courtroom. ...

Fourth, the district court's discretion must te exercised consistently with the First and Fifth Amendment rights of individuals to attend criminal trials. . . . Fifth, in the event someone who poses a threat of physical intimidation to the jurors appears and is excluded, the court need not stop the trial.

Id. at $* 1-2$.

35. Id. at $* 2$.

36. See Saundra Torry, Judge Reverses Ban on Attendance; Stallings Joins Spectators, WaSH. POST, July 7, 1990, at A1, A8.

37. $I d$.

38. Id. at A1.

39. See Twomey \& Brown, supra note 21 , at Al, Al3. 
case is scheduled for arraignment before a white judge. At the arraignment, Harvey wears a business suit and tie, and his jacket is accessorized by a colorful stole made of kente cloth. Kente cloth is a mutltihued woven fabric originally worn by ancient African royalty, and many African-Americans have adopted it as a fashion statement and a symbol of racial pride. ${ }^{40}$

In pretrial proceedings, the judge had warned Harvey that he would not be permitted to wear kente cloth before a jury. According to Harvey, the judge told him that wearing the fabric during a jury trial "was sending a hidden message to jurors." "41 The judge had informed Harvey that he had three options: He could refrain from wearing the kente cloth; he could withdraw from the case; or he could agree to try the case before the judge, without a jury. ${ }^{42}$ Harvey's client decided to plead guilty. At the June 11 hearing, however, Harvey refuses to enter his client's plea before the judge because he doubts that the judge will be impartial. The judge then removes Harvey from the case, "'not on the basis of [the] kente cloth, but on the basis that [Harvey] will not enter a plea which [his] client wishes to enter." 43

The same day, another client of Harvey's is scheduled to go to trial, also for assault with intent to kill, before another white judge. During the voir dire, the judge asks if any of the jurors are familiar with Harvey, whose battle with the other judge was well publicized. Four of the potential jurors know of the controversy. " [T] $]$ he concern we think we have here," the judge says, is " "that we won't influence a juror improperly." 44 He also informs them of case law in another jurisdiction suggesting that a court may prevent a Catholic priest from wearing a clerical collar in court. ${ }^{45}$ When Harvey asks the judge to inform the potential jurors of contrary cases, the judge refuses. The judge subsequently states:

"For the record, Mr. Harvey is black. Aside from the courtroom clerk, he is the only black person who is participating in this trial. . . . $\mathrm{He}$ is wearing a so-called kente cloth around his neck, and he has recently received wide publicity, which I am sure he loves.

"I have wondered with my own conscience whether for me to simply wait for the government or someone else to object is the

40. See Sabra Chartrand, A Dispute Over Courtroom Attire, and Principles, N.Y. TIMES, June 19, 1992, at B8; Charles Elder, African Clothes Attract Attention at Galleries; Kente-Cloth Garments Becoming Big Sellers, WaSH. PoST, Sept. 25, 1989, at F7.

41. Black D.C. Atty. Is At Odds With Judge Over Kente Cloth, JET, June 22, 1992, at 35.

42. Andrew Brownstein, Showdown Over Kente Cloth; D.C. Judge Takes Resolute Lawyer Off Case, WASH. POST, June 12, 1992, at A1, A18.

43. Id. (quoting Judge Robert M. Scott).

44. John Murawski, Colorful Cloth Has Judges Seeing Red, Legal TrMES, July 6, 1992, at 6, 6. The defendant in this case was Lebanese. See id. The judge did not express more specifically his concern that the cloth would prejudice black jurors, but it is possible that he thought it would make the jurors more sympathetic to either the nonwhite defendant or the African-American defense attorney. Harvey claimed that he wore the kente cloth for religious and cultural reasons. See id.

45. Id.; see La Rocca v. Lane, 338 N.E.2d 606 (N.Y. 1975), cert. denied, 424 U.S. 968 (1976). 
proper approach to avoid a war with Mr. Harvey, which I am not anxious for-either personally or on behalf of the Superior Court. . . . I also note that this is costing us all a lot of time ... and I don't appreciate it."

Ultimately, the judge allows Harvey to wear the cloth, but he suggests that when Harvey submits an attorney fee voucher to him for approval, he might not allow Harvey to be paid for the time the kente cloth issue has consumed. ${ }^{47}$ Harvey's client is tried before an all-black jury and is acquitted. ${ }^{48}$

\section{The Judicial and Popular Response: Willful Blindness}

As described above, the trial judge's attempt to exclude Farrakhan and Stallings from Barry's trial met with disapproval from the D.C. Circuit. In the case of John Harvey, no higher court had occasion to review the judge's prohibition against the kente cloth, ${ }^{49}$ but, as discussed below, much of the public reaction to the judge's prohibition was critical. ${ }^{50}$ These responses scorned the trial judge's fears that black jurors might acquit on the basis of racial identification rather than the "evidence." The D.C. Circuit and many observers, however, failed to acknowledge the significance of the "forbidden" message. I believe that this failure was deliberate. It reflected an intention to avoid serious consideration of the issue of black jurors acquitting black defendants on the basis of racial identification. Simply put, the D.C. Circuit and some of the public did not want to face the reality that race matters, in general and in jury adjudications of guilt and innocence.

\section{The D.C. Circuit: We Hate Fights}

The D.C. Circuit's per curiam opinion discussed the issue before it as though the judge's concern was that Barry's invitees would cause some type of physical disruption. The court listed a series of five "pertinent considerations," four of which actually were not pertinent because they involved the physical disruption of courtrooms or physical threats to witnesses.

46. Murawski, supra note 44 , at 6 .

47. Id. Under the District's Criminal Justice Act, an attorney assigned to a case must submit a "sworn written statement" for his or her attorney fees. See D.C. CODE ANN. § 11-2604 (1981).

48. Murawski, supra note 44 , at 6 .

49. Harvey sued the judge who removed him from the case for violating his First Amendment rights, see Lawyer's African Cloth of Faith Barred by Judge, CHI. TRIB., June 12, 1992, $\$ 1$, at 3, but the judge died before the case was resolved, see D.C. Superior Court Judge Robert M. Scott Dies at 70, WASH. POST, Sept. 17, 1992, at D5.

50. See, e.g., Donna Britt, Kente Cloth's Wiles Have Yet to Unfold, WASH. PosT, May 26, 1992, at B1; Judging the Kente Cloth. WASH. PoST, June 13, 1992, at A20.

51. United States v. Barry, Nos. 90-3150, 90-3149, \& 90-3151, 1990 WL 104925, at *1-2 (D.C. Cir. July 5,1990$)$. 
The only relevant consideration was so vague that it was nearly useless: The trial judge must exercise his discretion to exclude people from attending criminal matters "consistently with the First and Fifth Amendment rights of individuals to attend criminal trials." ${ }^{2}$ The court's discussion of this consideration is even more ambivalent: No one can be "wholly" excluded from a trial, even if he advocates a point of view that "we may regard as antithetical to the fair administration of justice" or if his presence sends an "undesirable message" to jurors. ${ }^{53}$ Because the appellate court did not suggest a procedure for partial exclusion of courtroom spectators, the trial judge's response was to pretend as though he had been concerned all along about physical disruption ${ }^{54}$ and subsequently to insist that Farrakhan and Stallings act in accordance with his rules of decorum. ${ }^{55}$ In the view of the D.C. Circuit, trial guests should keep their hands and their feet to themselves, but their messages may run amuck. In reality, Farrakhan's and Stallings's manners in the courtroom were an issue created by the appellate court. Ironically, the trial judge's response-the patronizing insistence that Farrakhan and Stallings agree to behave themselves-smacks of racism more than does his initial decision to exclude them from the courtroom.

United States v. Barry suggests that no trial spectator can be barred from a courtroom unless she threatens physically to disrupt the trial. In this respect, the court established a severe restriction on the discretion of judges to control public access to trials. Not all courts have taken this position, however. Two of the few other federal appellate courts that have considered symbolic communication by trial spectators have found it appropriate to regulate this type of communication. In one case, the Ninth Circuit stated that "[w]hen fair trial rights are at significant risk... the first amendment rights of trial attendees can and must be curtailed at the courthouse door." ${ }^{36}$ In another case, the Eleventh Circuit ordered the retrial of a man convicted of the murder of a prison guard, partly because of the presence, at the first trial, of numerous uniformed prison guards. ${ }^{57}$ The court was concerned that the guards' presence posed an unacceptable risk of prejudicing the jurors. ${ }^{58}$

Significantly, the decisions from the Ninth and Eleventh Circuits involved cases in which the presence of the spectators was not thought to implicate race.

52. Id. at $\neq 2$.

53. Id. (emphasis added).

54. Compare Torry, supra note 36 , at A1 (reporting judge's insistence that Farrakhan and Stallings act with "decorum") with Torry, supra note 23, at A13 (quoting judge's statement that Farrakhan's "'presence would be potentially disruptive, very likely intimidating, and he is a persona non grata for the [rest] of this case"").

55. See Torry, supra note 36 , at A1.

56. Norris v. Risley, 918 F.2d 828, 832 (9th Cir. 1990).

57. Woods v. Dugger, 923 F.2d 1454 (11th Cir.), cert. denied, 502 U.S. 953 (1991). In this case, the hidden message was pro-conviction, see id. at $1459-60$, unlike the pro-acquittal messages in the cases involving Barry and Harvey.

58. See id. 
The D.C. Circuit is the first appellate court to consider a "forbidden" racial message. ${ }^{59}$ My intention in noting this distinction is not to criticize the restrictive standard the D.C. Circuit established; indeed, there are potentially troubling implications of standards that allow trial judges more discretion in terms of which "secret" messages to regulate.$^{60} \mathrm{I}$ suggest, however, that the D.C. Circuit's holding was not mandated by clear constitutional dictates and was not supported by precedent from other federal jurisdictions. Indeed, other appellate courts have considered and regulated the contents of the messages that trial spectators were thought to be sending. Those cases suggest that the D.C. Circuit could have talked about race, and yet it did not.

\section{The Skeptics: What's Race Got to Do with It?}

The response of a number of commentators to the controversy over John Harvey's kente cloth was disdainful of the trial judge's apprehension about race-based appeals to black jurors. For example, the Washington Times characterized one of the judge's concerns as "[s]heer, unadulterated goofiness." ${ }^{.61}$ The editorial continued:

[The judge] apparently believes that the [kente] cloth is no innocent fabric but rather possesses hypnotic powers of seduction, powers that will turn the judicial system on its head and hold jurors in its sway.

....

... [W] hile most of us common folk are puzzled by this kind of judicial behavior, lawyers are widely inured to the fact that judges are free to act like fools with impunity-even when it is an abuse of discretion, an abuse of power, a waste of time and an injustice to someone who has come before the court seeking justice. ${ }^{62}$

The Washington Post opined:

There is absolutely no reason in logic or law for Judge Scott to tell Mr. Harvey that he cannot wear a kente cloth before a jury-regardless of the jurors' race. The very suggestion is offensive to black jurors, that they somehow lose their judgment and objectivity at the sight of a kente cloth. ${ }^{63}$

59. A New Jersey court, in the state trial of a white police officer accused of killing a black youth, prohibited the Rev. Al Sharpton, a controversial black activist, from attending. See Judge Bars Al Sharpton From Courtroom in Teaneck Trial, UPI, Jan. 2, 1992, available in LEXIS, News Library, UPI File. This decision was not appealed.

60. But for a critique of the circuit court's decision, see Terri A. Belanger, Note, Symbolic Expression in the Courtroom: The Right to a Fair Trial Versus Freedom of Speech, 62 GEo. WaSH. L. REV. 318 (1994).

61. Kente Cloth in the Dock, WASH. TIMES, June 13, 1992, at D2.

62. Id.

63. Judging the Kente Cloth, supra note 50, at A20. 
The National Bar Association, an African-American lawyers' group, expressed a similar concern, ${ }^{64}$ and one black attorney called the judge's actions "'almost unbelievable" and wondered why the judge "injected race" into the trial proceedings by making an issue of the kente cloth. ${ }^{65}$ Even the prosecutors in the kente cloth case "remained conspicuously silent" and refrained from endorsing the judge's concerns about the cloth. ${ }^{66}$

\section{The Forbidden Message Revealed}

I am fascinated by the refusal of these actors to take seriously the possibility and legal implications of black jurors' sympathy with black defendants. ${ }^{67}$ The criminal justice system would be better served if there were less reluctance to consider the significance of race in black jurors' adjudications of guilt or innocence. The remainder of this Essay argues that race matters when a black person violates American criminal law and when a black juror decides how she ${ }^{68}$ should exercise her power to put another black man in prison.

The idea that race matters in criminal justice is hardly shocking; it surely does not surprise most African-Americans. ${ }^{69}$ In the Barry and Harvey stories, I believe that it was known by all of the key players: judges, jurors, attorneys, defendants, and spectators. The trial judges in those cases were correct: Somebody - the controversial black demagogue, the radical black priest, the kente-cloth-wearing lawyer-was trying to send the black jurors a message. The message, in my view, was that the black jurors should consider the evidence presented at trial in light of the idea that the American criminal

64. See Chartrand, supra note 40 , at B8.

65. Murawski, supra note 44, at 6 (quoting attomey Nathaniel Speights).

66. Id.

67. Given that acknowledgement of my premise is widespread enough to be incorporated into a training session at the U.S. Attorney's Office, the dearth of scholarship on the issue initially seems surprising. In fact, precious few members of the legal academy write about the intersection of race and crime at all. See Norval Morris, Race and Crime: What Evidence Is There That Race Influences Results in the Criminal Justice System?, 72 JUDICATURE 111, 112 (1988) ("It's no good going to the legal scholars of this country to answer [the question posed in the title], they don't deal with it, they don't write about it, and they don't discuss it publicly.").

To the extent that this Essay makes a case for letting guilty black criminals go free, it lends itself to the description "radical." The label is one I accept proudly, because it suggests the degree of my discomfort with the status quo. The label is not, however, the most comfortable appellation for one who wishes to be heard in the current political climate. So I ask the reader to remember that if my thesis is radical, then so too are many ordinary black people when they approach their work as jurors.

68. As will be seen below, I use "he" when referring to defendants because most defendants are male and "she" when referring jurors, both to counter the sexist implications of using the generic "he" and to distinguish the juror from the defendant. I do not intend to connote any special gender roles by my use of these pronouns.

69. See infra Subsection II.A.3. 
justice system discriminates against blacks. The message was that the jurors should not send another black man to prison. ${ }^{70}$

There is no way to "prove" what Farrakhan's and Stallings's purposes were in attending Barry's trial-nor can I "prove" the intent of the kente-clothwearing lawyer. I believe that my theory that they were encouraging black jurors' sympathy is reasonable, based on the relevant players' statements, the trial judge's observations, and common sense and experience. Even if one is unwilling to ascribe to those players the same racially based motivations that I do, acknowledgement and concern that some black jurors acquit black defendants on the basis of race are increasing, as my experience at the U.S. Attorney's Office showed. For the remainder of this Essay, I focus on the legal and social implications of this conduct by black jurors.

\section{II. "JUSTICE OUTSIDE THE FORMAL RULES OF LAW""1}

Why would a black juror vote to let a guilty person go free? Assuming that the juror is a rational actor, she must believe that she and her community are, in some way, better off with the defendant out of prison than in prison. But how could any rational person believe that about a criminal? The following section describes racial critiques of the American criminal justice system. I then examine the evolution of the doctrine of jury nullification and argue that its practice by African-Americans is, in many cases, consistent with the Anglo-American tradition and, moreover, is legally and morally right.

\section{A. The Criminal Law and African-Americans: Justice or "Just us"? ?2}

Imagine a country in which more than half of the young male citizens are under the supervision of the criminal justice system, either awaiting trial, in prison, or on probation or parole. ${ }^{73}$ Imagine a country in which two-thirds of

70. An African-American poet described a black juror who vated, along with 11 white male jurors, against the interests of a black person in this way:

[The white male jurors] dragged her 4'10" black woman's frame

over the hot coals of four centuries of white male approval

until she let go the first real power she ever had

and lined her own womb with cement

to make a graveyard for our children.

AUdRe LORDE, Power, in THE BLACK UNICORN 108, 109 (1978). The kente cloth says "don't do that."

71. United States v. Dougherty, 473 F.2d 1113, 1137 (D.C. Cir. 1972) (describing scope of interests served by jury system).

72. "Just us" is a familiar pun in the African-American community. See, e.g., Henry L. Gates, Jr., Thirteen Ways Of Looking At A Black Man, NEw YORKER, Oct. 23, 1995, at 56, 58 ("As older blacks like to repeat, "When white folks say "justice," they mean "just us."'”).

73. One study found that, in Baltimore, Maryland, 56\% of the African-American males between the ages of 18 and 35 were under criminal justice supervision on any given day in 1991. NATIONAL CTR. ON INSTITUTIONS AND ALTERNATIVES, HOBBLING A GENERATION: YOUNG AFRICAN AMERICAN MALES IN THE CRIMINAL JUSTICE SYSTEM OF AMERICA's CITIES: BALTIMORE, MARYLAND 1 (1992). In Washington, D.C., this number was $42 \%$. JEROME G. MILLER, HOBBLING A GENERATION: YOUNG AFRICAN AMERICAN MALES 
the men can anticipate being arrested before they reach age thirty ${ }^{74}$ Imagine a country in which there are more young men in prison than in college. ${ }^{75}$ Now give the citizens of the country the key to the prison. Should they use it?

Such a country bears some resemblance to a police state. When we criticize a police state, we think that the problem lies not with the citizens of the state, but rather with the form of government or law, or with the powerful elites and petty bureaucrats whose interests the state serves. Similarly, racial critics of American criminal justice locate the problem not so much with the black prisoners as with the state and its actors and beneficiaries. As evidence, they cite their own experiences and other people's stories, ${ }^{76}$ African-American history, understanding gained from social science research on the power and pervasiveness of white supremacy, and ugly statistics like those in the preceding paragraph.

For analytical purposes, I will create a false dichotomy among racial critics by dividing them into two camps: liberal critics and radical critics. Those are not names that the critics have given themselves or that they would necessarily accept, and there would undoubtedly be disagreement within each camp and

IN WAShington, D.C.'s CRIMINAL JuSTICE System 1 (1992); see also Jerome G. Miller, From Social Safety Net to Dragnet: African-American Males in the Criminal Justice System, 51 WASH. \& LEE L. REV. 479, 487-88 (1994).

Evidence on which to base comparisons with other groups is relatively scarce. For example, similar figures are not available for Latinos, see Robert Garcia, Latinos and Criminal Justice, 14 CHICANO-LATINO L. REv. 6, 7 (1994), although a Justice Department study found that $14 \%$ of state inmates in 1990 were Hispanic, see U.S. DEP'T OF JustiCE, BuREAU OF JustiCE STATISTICS, CORRECTIONAL POPULATIONS IN THE UNITED STATES, 1990, at 9 (1990).

74. In California, nearly two-thirds of all black males are arrested at some point between the ages of 18 and 30. See Robert Tillman, The Size of the "Criminal Population:" The Prevalence and Incidence of Adult Arrest, 25 CRIMINology 561, 567, 576 (1987) (finding that by age 30,65.5\% of black males in California who turned 18 in 1974 had been arrested).

75. In $1991,583,545$ blacks were in local jails (188,300 people) or under the jurisdiction of state and federal correctional authorities (395,245 people). See U.S. DEP'T OF JUSTICE, BUREAU OF JUSTICE STATISTICS, SOURCEBOOK OF CRIMINAL JUSTICE STATISTICS 1993, at 592, 606 (1994) [hereinafter SOURCEBOOK 1993]. The number of black men in college in the same year was approximately 517,000 . STATISTICAL ABSTRACT 1994, supra note 13, at 178.

76. See Gates, supra note 72 , at 58 . As Gates recounts:

Blacks-in particular, black men-swap their [negative] experiences of police encounters like war stories, and there are few who don't have more than one story to tell. "These stories have a ring of cliche about them," Erroll McDonald, Pantheon's executive editor and one of the few prominent blacks in publishing, says, "but, as we all know about clichés, they're almost always true." McDonald tells of renting a Jaguar in New Orleans and being stopped by the police-simply "to show cause why I shouldn't be deemed a problematic Negro in a possibly stolen car." [The jazz trumpeter] Wynton Marsalis says, "Shit, the police slapped me upside the head when I was in high school. I wasn't Wynton Marsalis then. I was just another nigger standing out somewhere on the street whose head could be slapped and did get slapped." The crime novelist Walter Mosley recalls, "When I was a kid in Los Angeles, they used to stop me all the time, beat on me, follow me around, tell me that I was stealing things." Nor does [sociologist] William Julius Wilson ... wonder why he was stopped near a small New England town by a policeman who wanted to know what he was doing in those parts. There's a moving violation that many African-Americans know as D.W.B.: Driving While Black.

Id. at 58-59. Gates concludes that, as "Wynton Marsalis says, "My worst fear is to have to go before the criminal-justice system.' Absurdly enough, it's mine, too." Id. at 59. 
theoretical overlap between the camps. Nonetheless, for the purposes of a brief explication of racial critiques, my oversimplification may be useful.

\section{The Liberal Critique}

According to this critique, American criminal justice is racist because it is controlled primarily by white people, who are unable to escape the culture's dominant message of white supremacy, and who are therefore inevitably, even if unintentionally, prejudiced. ${ }^{77}$ These white actors include legislators, police, prosecutors, judges, and jurors. They exercise their discretion to make and enforce the criminal law in a discriminatory fashion. ${ }^{78}$ Sometimes the discrimination is overt, as in the case of Mark Fuhrman, the police officer in the O.J. Simpson case who, in interviews, used racist language and boasted of his own brutality ${ }^{79}$ and sometimes it is unintentional, as with a hypothetical white juror who invariably credits the testimony of a white witness over that of a black witness.

The problem with the liberal critique is that it does not adequately explain the extent of the difference between the incidence of black and white crime, especially violent crime. For example, in 1991, blacks constituted about fiftyfive percent of the 18,096 people arrested for murder and non-negligent manslaughter in the United States (9924 people). ${ }^{80}$ One explanation the liberal critique offers for this unfortunate statistic is that the police pursue black murder suspects more aggressively than they do white murder suspects. In other words, but for discrimination, the percentage of blacks arrested for murder would be closer to their percentage of the population, roughly twelve percent. $^{81}$ The liberal critique would attribute some portion of the additional forty-three percent of non-negligent homicide arrestees (in 1991, approximately 7781 people $^{82}$ ) to race prejudice. Ultimately, however, those assumptions strain credulity, not because many police officers are not racist, but because there is no evidence that there is a crisis of that magnitude in criminal justice.

77. For a general discussion of this critique, see CORAMAE R. MANN, UNEQUAL JUSTICE: A QUESTION OF COLOR (1993). For a discussion of the impact of white supremacy on whites in general, see Edward $P$. Boyle, It's Not Easy Bein' Green: The Psychology of Racism, Environmental Discrimination, and the Argument for Modernizing Equal Protection Analysis, 46 VAND. L. REV. 937, 940-45 (1993), and on liberal whites in particular, see Naomi Wolf, The Racism of Well-Meaning White People, GLAmour, Aug. 1995 , at 230.

78. See Gary Peller, Criminal Law, Race, and the Ideology of Bias: Transcending the Critical Tools of the Sixties, 67 TUL. L. REV. 2231, 2231 (1993) (arguing that "[n]o fancy theoretical conceptualization is necessary to explain how race figures in police brutality, in prosecutorial decisions, in jury selection, in conviction rates, and in the incarceration and capital sentencing of people of color in America").

79. See Charles Madigan, A Bad Day for Cops; Police Feeling Heat; Experts Cite Improvements in Race Relations, CHI. TRIB., Aug. 31, 1995, $\$ 1$, at 1 (describing police reactions to disclosure of recordings of Fuhrman making racist statements).

80. See U.S. DEP'T OF JustiCE, BuREAU OF JustiCE STATISTICS, SOURCEBOOK OF CRIMINAL JUSTICE STATISTICS 1992, at 434 (1993) [hereinafter SOURCEBOOK 1992].

31. See STATISTICAL ABSTRACT 1994, supra note 13, at 13.

82. See SOURCEBOOK 1992, supra note 80, at 434. 
In fact, for all the faults of American law enforcement, catching the bad guys seems to be something it does rather well. The liberal critique fails to account convincingly for the incidence of black crime.

\section{The Radical Critique}

The radical critique does not discount the role of discrimination in accounting for some of the racial disparity in crime rates, but it also does not, in contrast to the liberal critique, attribute all or even most of the differential to police and prosecutor prejudice. The radical critique offers a more fundamental, structural explanation.

It suggests that criminal law is racist ${ }^{83}$ because, like other American law, it is an instrument of white supremacy. ${ }^{84}$ Law is made by white elites to protect their interests and, especially, to preserve the economic status quo, which benefits those elites at the expense of blacks, among others ${ }^{85}$ Due to discrimination and segregation, the majority of African-Americans receive few meaningful educational and employment opportunities and, accordingly, are unable to succeed, at least in the terms of the capitalist ideal ${ }^{86}$ Some property crimes committed by blacks may be understood as an inevitable result of the tension between the dominant societal message equating possession of material resources with success and happiness and the power of white supremacy to

83. In the legal academy, this critique has been advanced by only a few critical race theorists, see, e.g., DERRICK BELL, RACE, RACISM AND AMERICAN LAW 329-47 (3d ed. 1992); Regina Austin, "The Black Community," Its Lawbreakers, and a Politics of Identification, 65 S. CAL. L. REV. 1769, 1780-81 (1992) (noting relationship between black poverty and decisions to engage in criminal activity); Dorothy $\mathrm{E}$. Roberts, Punishing Drug Addicts Who Have Babies: Women of Color, Equality, and the Right of Privacy, 104 HARV. L. REV. 1419, 1435-36 (1991), and by even fewer critical legal studies scholars, see, e.g., Peller, supra note 78 , at 2231,2248 . In the legal academy generally, racial critiques, especially radical ones, are rarely heard. See id. at 2231 (noting that "[t]he very ease with which the racial bias of the criminal justice system can be described ... has perhaps fostered a lack of serious critical consideration of how criminal law interacts with American racism"); see also Katheryn $\mathrm{K}$. Russell, A Critical View from the Inside: An Application of Critical Legal Studies to Criminal Law, 85 J. CRIM. L. \& CRIMINOLOGY 222, 222-26 (1993) (noting paucity of critical legal studies work on criminal law). As Randall Kennedy astutely suggests, however, there are advocates of racial critiques of criminal justice in popular culture, primarily rap musicians. See Randall Kennedy, The State, Criminal Law, and Racial Discrimination: A Comment, 107 HARV. L. REV. 1255, 1258 n.10 (1994) (citing "F*ck Tha Police" by rap group N.W.A.).

84. See BELL, supra note 83, at 46-50, 60-63; Dorothy E. Roberts, Crime, Race, and Repraduction, 67 TUL. L. REV. 1945, 1945-47 (1993).

85. Cf. Derrick Bell, The Racism is Permanent Thesis: Courageous Revelation or Unconscious Denial of Racial Genocide, 22 CAP. U. L. REV. 571, 571 (1993) (arguing that "[w]ithout the deflecting power of racism, masses of whites would likely wake up to and revolt against the severe disadvantage they suffer in income and opportunity when compared with those whites at the top of our socio-economic heap"). Bell notes that the economic status quo also provides little benefit for most white Americans. He cites statistics suggesting that individuals in the nation's top one-fifth in terms of income earn more than the other fourfifths combined, and that the top two million income earners eam more than the next one hundred million combined. See id. at 576. For a Marxist analysis of the relationship between race and class in a capitalist system, see MELVIN M. LEIMAN, POLITICAL ECONOMY OF RACISM (1993).

86. Cf. Good For Business: Making Full Use of the Nation's Human Capital, Daily Lab. Rep. (BNA) No. 52 (Mar. 17, 1995) (reporting results of study that show that, despite 30 years of affirmative action, $95 \%$ of senior management positions are still held by white men, who constitute $43 \%$ of work force). 
prevent most African-Americans from acquiring "enough" of those resources in a legal manner. "Black-on-black" violent crime, and even "victimless" crime like drug offenses, can be attributed to internalized racism, which causes some African-Americans to devalue black lives-either those of others or their own. The political process does not allow for the creation or implementation of effective "legal" solutions to this plight, ${ }^{87}$ and the criminal law punishes predictable reactions to it. ${ }^{88}$

I am persuaded by the radical critique when I wonder about the roots of the ugly truth that blacks commit many crimes at substantially higher rates than whites. Most white Americans, especially liberals, would publicly offer an environmental, as opposed to genetic, explanation for this fact. ${ }^{89}$ They would probably concede that racism, historical and current, plays a major role in creating an environment that breeds criminal conduct. From this premise, the radical critic deduces that but for the (racist) environment, the AfricanAmerican criminal would not be a criminal. In other words, racism creates and sustains the criminal breeding ground, which produces the black criminal. Thus, when many African-Americans are locked up, it is because of a situation that white supremacy created.

Obviously, most blacks are not criminals, even if every black is exposed to racism. To the radical critics, however, the law-abiding conduct of the majority of African-Americans does not mean that racism does not create black criminals. Not everyone exposed to a virus will become sick, but that does not mean that the virus does not cause the illness of the people who do.

The radical racial critique of criminal justice is premised as much on the criminal law's effect as on its intent. The system is discriminatory, in part, because of the disparate impact law enforcement has on the black

87. See Tilden J. LeMelle, Foreword to RICHARD M. BURKEY, RACIAL DISCRIMINATION AND PUBLIC POLICY IN THE UNITED STATES at $x$ (1971) (questioning "whether a society such as that of the United States is really capable of legislating and enforcing effective public policy to combat racial discrimination").

88. See, e.g., john a. powell \& Eileen B. Hershenov, Hostage to the Drug War: The National Purse, the Constitution and the Black Community, 24 U.C. DAVIS L. REv. 557, 609-14 (1991) (arguing that disproportionate number of black men prosecuted for drug-related crimes is evidence that arrests target black community and are form of institutionalized racism); Roberts, supra note 84, at 1946 (arguing that "[t]he American criminal justice system has historically served as a means of controlling blacks"). For a discussion of the role of white supremacy in facilitating black-on-black crime, see Derrick Bell, Learning the Three "I's" of American Slave Heritage, 68 CHI.-KENT L. REV. 1037, 1046 (1993) ("Victimized themselves by an uncaring society, some young blacks vent their rage on victims like themselves, thereby perpetuating the terror that once whites had to invoke directly."), and Stephen L. Carter, When Victints Happen to Be Black, 97 YALE L.J. 420, 427 (1988) (describing, but not endorsing, theory that black-onblack crime is "statement of frustration" and that if you "[r]emove the sources of the frustration-the racism, the 'structural' unemployment, the inadequate education . . . you eliminate much of the violence").

89. When I say that most white Americans would "publicly" offer an environmental explanation for the relationship between race and crime, I mean that they would not publicly endorse a genetic theory, even if they believed such a theory to be true. But $c f$. RICHARD J. HERRNSTEIN \& CHARLES MURRAY, THE BELL CURVE (1994) (giving genetic "explanation" and arguing that most white Americans actually endorse that explanation). 
community. ${ }^{90}$ This unjust effect is measured in terms of the costs to the black community of having so many African-Americans, particularly males, incarcerated or otherwise involved in the criminal justice system. These costs are social and economic, and include the perceived dearth of men "eligible" for marriage, ${ }^{91}$ the large percentage of black children who live in femaleheaded households, ${ }^{92}$ the lack of male "role models" for black children, especially boys, ${ }^{93}$ the absence of wealth in the black community, ${ }^{94}$ and the large unemployment rate among black men. ${ }^{95}$

\section{Examples of Racism in Criminal Justice}

Examples commonly cited by both liberal and radical critics as evidence of racism in criminal justice include: the Scottsboro case; ${ }^{96}$ the history of the criminalization of drug use $;{ }^{97}$ past and contemporary administration of the

90. As I discuss below, some people regard effects-based racial critiques of criminal law as counterproductive and ultimately harmful to the black community. See infra Subsection II.A.4. There is, however, precedent in other areas of the law, e.g., employment discrimination law, suggesting that a racially disparate effect is either prima facie evidence of racial discrimination or otherwise indicative of a practice or policy that should be changed. See, e.g., Griggs t. Duke Power Co., 401 U.S. 424, 431 (1971) (holding that Title VII of Civil Rights Act of 1964 "proscribes not only overt discrimination but also practices that are fair in form, but discriminatory in operation"). Legal scholars have described theories of discrimination that seek remedies for disparate racial effects as coming from "outsider" or "victim" jurisprudential perspectives. See, e.g., Mari J. Matsuda, Public Response to Racist Speech: Considering the Victim's Story, 87 MICH. L. REV. 2320 (1989). In fact, this perspective may be gaining more influence in criminal law. For example, the United States Sentencing Commission recently recommended that the distinction between powdered cocaine and base ("crack") cocaine, see infra note 103, be eliminated, based in part on the racially disparate effect. See Correcting Cocaine Injustice, N.Y. TiMES, Mar. 9, 1995, at A24.

91. See TERRY MCMILlAN, WAITING To Exhale 332 (1992) (listing incarceration as one of number of factors to which black female characters in book attribute lack of available black men).

92. In 1993 , there were $5,757,000$ black children under the age of 18 who lived with their mother only, while $3,796,000$ black children under the age of 18 lived with both parents. STATISTICAL ABSTRACT 1994, supra note 13, at 67.

93. See Detroit Pub. Sch., Male ACademy Grades K-8: A Demonstration Program for AtRISK MALES 26 (1991); Rogers Worthington, Milwaukee Idea Shapes a New School, CHI. TRIB., Dec. 1, 1991, at 25 .

94. The median income for black households in 1992 was $\$ 18,660$, while the median income for all households in 1992 was $\$ 30,786$. STATISTICAL ABSTRACT 1994, supra note 13, at 464 .

95. The unemployment rate for black males in 1993 was $13.8 \%$, id. at 403 , as opposed to $6.8 \%$ for all workers, id. at 396. Ex-convicts, many of whom are black, often find it more difficult to find employment. See, e.g., Chi Chi Sileo, Men Forced to March to Different Drummer; Boot Camps Try to Turn Offenders Around, WASH. TIMES, July 6, 1994, at A9 (stating that most employment programs for ex-convicts have less than $50 \%$ placement rate).

96. In the 1930s, nine black youths were riding a freight train in Alabama when a fight broke out after a white male stepped on the hand of one of the youths. Several white males were thrown off the train as a result of the fight. Hearing reports of the melee, dozens of armed white men stopped the train and locked the black youths in a Scottsboro, Alabama jail. Two white, female passengers on the train accused the black youths of having raped them. At trial, eight of the youths were convicted and sentenced to die; a mistrial was declared in the case of the ninth defendant. The defendants were reindicted several times after the U.S. Supreme Court reversed the convictions and sentences on the ground of racial discrimination. See generally DAN T. CARTER, SCOTTSBORO: A TRAGEDY OF THE AMERICAN SOUTH (1969) (providing detailed historical account of Scottsboro cases); JAMES GOODMAN, STORIES OF SCOTTSBORO (1994) (providing narrative of Scottsboro cases and their effects on life during the Depression).

97. Cf. TROY DUSTER, THE LEGISLATION OF MORALITY (1970) (showing how moralistic judgments are made to criminalize previously accepted practices and behavior). See generally DAVID F. MUSTO, THE 
death penalty $;^{98}$ the use of imagery linking crime to race in the 1988 presidential campaign ${ }^{99}$ and other political campaigns; ${ }^{100}$ the beating of Rodney King and the acquittal of his police assailants; ${ }^{101}$ disparities between punishments for white-collar crimes and punishments for other crimes; ${ }^{102}$ more severe penalties for crack cocaine users than for powder cocaine users; ${ }^{103}$ the Charles Murray and Susan Smith cases; ${ }^{104}$ police corruption scandals in minority neighborhoods in New York and Philadelphia; ${ }^{105}$ the O.J. Simpson case, including the extraordinary public and media fascination with it, ${ }^{106}$ the racist police officer who was the prosecution's star

AMERICAN DISEASE: ORIGINS OF NARCOTIC CONTROL (1973) (reviewing history of cocaine use and narcotic control in United States); Patricia A. Morgan, The Legislation of Drug Law: Economic Crisis and Social Control, 8 J. DRUG IssuES 53 (1978) (examining prosess of early drug legislation through look at California's first opium law).

98. See McCleskey v. Kemp, 481 U.S. 279, 312-13 (1987) (stating that racial disparities in sentencing are unavoidable part of criminal justice system and do not violate Constitution); see also Randall $\mathrm{L}$. Kennedy, McCleskey v. Kemp: Race, Capital Punishment, and the Supreme Court, 101 HARv. L. REv. 1388 (1988).

99. See, e.g., Susan Estrich, The Politics of Race; When George Bush Made Willie Horton Part of His Campaign Team, the Issue Wasn't Just Crime-It Was Racial Fear. Michael Dukakis' Campaign Manager Saw It Happening, and Blames Herself for Not Speaking Out, WASH. PoST, Apr. 23, 1989, Magazine, at W20.

100. See, e.g., Peter Applebome, Helms Kindled Anger in Campaign, and May Have Set Tone for Others, N.Y. TIMES, Nov. 8, 1990, at B3 (reporting on Jesse Helms's use of racial imagery in his senatorial campaign against black challenger Harvey Gantt); Cathleen Decker, Race Often Plays Real but Unspoken Role in Politics; Campaigns: Candidates Shun Overt Appeals to Prejudice, but Social Scientists Say It Underlies Many Issues, L.A. TIMES, Oct. 16, 1994, at A1 (discussing racial undertones of political advertisements in California on crime, immigration, and welfare reform).

101. See generally INDEPENDENT COMM'N ON THE L.A. POLICE DEP'T, REPORT OF THE INDEPENDENT COMMISSION ON THE LOS ANGELES POLICE DEPARTMENT 9-17 (1991) (recounting police beating of Rodney King and its repercussions).

102. See James W. Coleman, The Criminal Elite: The Sociology of White Collar Crime 168 (1985) (noting that "white collar criminals receive much more lenient sentences than other criminals receive"); $c f$. EDWIN H. SUTHERLAND, WHITE COLLAR CRIME: THE UNCUT VERSION 56-60 (1983) (discussing tendency of public to view white-collar crimes with less resentment than other crimes).

103. The Federal Sentencing Guidelines treat one gram of crack as equivalent to 100 grams of powder cocaine for sentencing purposes. See U.S. SENTENCING COMM'N, FEDERAL SENTENCING GUIDELINES MANUAL \$ 2D1.1(c) (1994) (listing substance quantities and corresponding base offense levels). In State v. Russell, 477 N.W.2d 886 (Minn. 1991), the Minnesota Supreme Court invalidated Minnesota's sentencing scheme, which punished possession of crack more severely than powder cocaine. Id. at 891. In Minnesota in 1988, approximately $97 \%$ of all persons charged with possession of crack were black, while approximately $80 \%$ of all persons charged with possession of powdered cocaine were white. Id. at $887 \mathrm{n} .1$; see also Kennedy, supra note 83, at 1262 (citing Russell, 477 N.W.2d at 887 n.1); Matthew F. Leitman, A Proposed Standard of Equal Protection Review for Classifications Within the Criminal Justice System That Have a Racially Disparate Impact: A Case Study of the Federal Sentencing Guidelines' Classification Between Crack and Powder Cocaine, 25 U. TOL. L. REV. 215, 216 (1994) (same); Knoll D. Lowney, Smoked Not Snorted: Is Racism Inherent in Our Crack Cocaine Laws?, 45 WASH. U. J. URB. \& CONTEMP. L. 121,162 n.232 (1994) (same).

104. See Michael Quintanilla, Divided We Stand; Boston. South Carolina. Oklahoma City. The Misplaced Finger of Blame in Each Case Points up the Delicate Nature of Race Relations, L.A. TIMES, Apr. 28, 1995, at E1.

105. See N.R. Kleinfield with James C. McKinley, Jr., Paths to Scandal: A Special Report; Stories of Courage and Sacrifice, Corruption and Betrayal in Blue, N.Y. TIMES, Apr. 25, 1994, at A1; Don Terry, Philadelphia Shaken by Criminal Police Officers, N.Y. TIMES, Aug. 28, 1995, at Al.

106. See, e.g., Lloyd Grove, Race and the Simpson Case; As the Story Unfolds, Debate Simmers over the Color Question, WASH. POST, June 27, 1994, at D1; Jim Newton \& Andrea Ford, Lawyers Bitterly 
witness, ${ }^{107}$ and the response of many white people to the jury's verdict of acquittal; ${ }^{108}$ and, cited most frequently, the extraordinary rate of incarceration of African-American men. ${ }^{109}$

\section{Law Enforcement Enthusiasts}

Of course, the idea that the criminal justice system is racist and oppressive is not without dissent, and among the dissenters are some African-Americans. Randall Kennedy succinctly poses the counterargument:

Although the administration of criminal justice has, at times, been used as an instrument of racial oppression, the principal problem facing African-Americans in the context of criminal justice today is not over-enforcement but under-enforcement of the laws. The most lethal danger facing African-Americans in their day-to-day lives is not white, racist officials of the state, but private, violent criminals (typically black) who attack those most vulnerable to them without regard to racial identity. ${ }^{110}$

According to these theorists, whom I will call law enforcement enthusiasts, the criminal law may have a disproportionate impact on the black community, but this is not a moral or racial issue because the disproportionate impact is the law's effect, not its intent. For law enforcement enthusiasts, intent is the most

Debate Race in Simpson Case, L.A. TIMES, Jan. 14, 1995, at A1; Adam Pertman, Race Comes to Fore in Simpson Case, Boston GloBE, Jan. 14, 1995, at 1.

107. See Madigan, supra note 79 , at 1.

108. See Gates, supra note 72 , at 56 . Gates notes:

[I]n the aftermath of the Simpson trial the focus of attention has been swiftly displaced from the verdict to the reaction to the verdict, and then to the reaction to the reaction to the verdict, and, finally, to the reaction to the reaction to the reaction to the verdict-which is to say, black indignation at white anger at black jubilation at Simpson's acquittal.

Id.; see also Courtland Milloy, In White Riot, It's Smolder, Baby, Smolder, WASH. PosT, Oct. 8, 1995, at Bl ("Have you ever seen a white riot? It started when O.J. Simpson was acquitted. It's not like in the early 1900 's when they'd lynch you if they thought justice had not been served. It's more subtle now . ....").

109. Blacks constituted $12.4 \%$ of the United States population in 1992, STATISTICAL ABSTRACT 1994, supra note 13, at 13 , but represented $30.3 \%$ of all arrests, id. at 205 . In the same year, blacks constituted $44.1 \%$ of all jail inmates, SOURCEBOOK 1993 , supra note 75 , at 592 , and nearly $48 \%$ of those under the jurisdiction of state and federal correctional authorities, see id. at 606 .

110. Kennedy, supra note 83, at 1259 (footnotes omitted); see also Thomas Sowell, Vigilantes in Los Angeles: Before We Give In to a Lynch-Mob Mentality, We Have to Look Beyond Chief Gates, ARIz. REPUBLIC, Mar. 24, 1991, at C5 (arguing that restrictions on conduct of law enforcement officials, especially restrictions set out by judiciary, have resulted in inadequate protection for law-abiding citizens). There is no doubt that African-Americans are disproportionately the victims of crime. For example, in 1992, blacks accounted for approximately $49 \%$ of all murder victims. STATISTICAL ABSTRACT 1994, supra note 13. at 201: see also Ralph R. Reiland, If They Do the Crime ... Why Shouldn't They Do Most of the Time?, CHI. TRIB., Mar. 17, 1995, at 19 (stating that $95 \%$ of black murder victims are murdered by other blacks and quoting African-American former police chief of Washington, D.C. as saying that "[w]e would riot if whites killed this many blacks"). 
appropriate barometer of governmental racism. ${ }^{111}$ Because law enforcement is a public good, it is in the best interest of the black community to have more, rather than less, of it. Allowing criminals to live unfettered in the community would harm, in particular, the black poor, who are disproportionately the victims of violent crime. Indeed, the logical conclusion of the enthusiasts' argument is that African-Americans would be better off with more, not fewer, black criminals behind bars.

To my mind, the enthusiasts embrace law enforcement too uncritically: They are blind to its opportunity costs. I agree that criminal law enforcement constitutes a public good for African-Americans when it serves the social protection goals that Professor Kennedy highlights. In other words, when locking up black men means that "violent criminals ... who attack those most vulnerable"112 are off the streets, most people-including most law enforcement critics-would endorse the incarceration. But what about when locking up a black man has no or little net effect on public safety, when, for example, the crime with which he was charged is victimless? ${ }^{113}$ Putting aside for a moment the legal implications, couldn't an analysis of the costs and benefits to the African-American community present an argument against incarceration? I argue "yes," in light of the substantial costs to the community of law enforcement. I accept that other reasonable people may disagree. But the law enforcement enthusiasts seldom acknowledge that racial critics even weigh the costs and benefits; their assumption seems to be that the racial critics are foolish or blinded by history or motivated by their own ethnocentrism. ${ }^{14}$

111. Professor Kennedy makes the argument concisely:

[S]ome condemn as "genocide" the punitive "war on drugs" because a disproportionate number

of those subjected to arrest, prosecution, and incarceration for drug use are black. . . . No one

[however] . . . has come forward with credible evidence to suggest that American drug policy

is truly genocidal - that is, deliberately designed to eradicate a people.

Kennedy, supra note 83 , at 1261 (footnote omitted). Ironically, that racist intent may be measured by the number of black criminals who are not imprisoned or executed. Some enthusiasts argue that underenforcement of the criminal law in the African-American community may be the result of a willful reluctance to protect the interests of black victims. See id. at 1256 (arguing that underenforcement in black communities "often stems from a pervasive and racist devaluation of black victims of crime"). In McCleskey v. Kemp, 481 U.S. 279 (1987), the Supreme Court considered an empirical study that claimed that black murderers were significantly more likely to receive the death penalty if their victims were white. The Court held that there were too many variables present in capital cases for the study to prove conclusively what it purported to prove. The Court noted, however, that "[t]here is, of course, some risk of racial prejudice influencing a jury's decision in a criminal case. . . . The question is "at what point that risk becomes constitutionally unacceptable." Id. at 308-09 (quoting Tumer v. Murray, 476 U.S. 28, 36 n.8 (1986)). Professor Kennedy has argued that the risk is unacceptable when the black community loses the benefit of equal protection of the criminal law. See Kennedy, supra note 98, at 1421-29. He maintains that "the unfairness that race-of-the-victim discrimination visits upon the black community [lies in] denying it equal treatment with respect to those who kill its members." Id. at 1391.

112. Kennedy, supra note 83 , at 1259.

113. See infra Section III.A.

114. Professor Kennedy, for example, writes:

[Racial critics] frequently proceed as if there existed no dramatic discontinuities in American history, as if there existed little difference between the practices and sentiments that 


\section{The Body Politic and the Racial Critiques}

I suspect that many white people would agree with the racial critics' analysis, even if most whites would not support a solution involving the emancipation of black criminals. I write this Essay, however, out of concern for African-Americans and how they can use the power they have now to create change. The important practicability question is how many AfricanAmericans embrace racial critiques of the criminal justice system and how many are law enforcement enthusiasts?

According to a recent USA Today/CNN/Gallup poll, sixty-six percent of blacks believe that the criminal justice system is racist and only thirty-two percent believe it is not racist. ${ }^{115}$ Interestingly, other polls suggest that blacks also tend to be more worried about crime than whites; ${ }^{116}$ this seems logical when one considers that blacks are more likely to be the victims of crime. ${ }^{117}$ This enhanced concern, however, does not appear to translate into endorsement of tougher enforcement of traditional criminal law. For example, substantially fewer blacks than whites support the death penalty, ${ }^{118}$ and many more blacks than whites were concerned with the potential racial consequences of the strict provisions of the Crime Bill of $1994 .{ }^{119}$ While polls are not, perhaps, the most reliable means of measuring sentiment in the African-American

characterized the eras of slavery and de jure segregation and those prevalent today, as if African-Americans had completely failed in their efforts to reform and participate in the creation and implementation of government policy ....

Kennedy, supra note 83 , at 1258 . Kennedy later argues that racial critics' solutions to black criminal victimization are "confused and hobbled by a reffexive, self-defeating resort to charges of racism." Id. at 1260 .

115. See Maria Puente, Poll: Blacks' Confidence in Police Plummets, USA TodaY, Mar. 21, 1995, at $3 \mathrm{~A}$. Only $37 \%$ of whites expressed a belief that the system is racist, while $59 \%$ of whites said it was not racist. Id. The poll's finding on attitudes toward police are even more revealing. Only 33\% of blacks agreed with the proposition that police generally testify truthfully. Id. In stark contrast, $70 \%$ of whites expressed the view that police generally testify truthfully. Id. Other polls have found similar results with regard to black attitudes towards criminal justice. See, e.g., U.S. Blacks See Media, Law Bias, UPI, July 16, 1994, available in LEXIS, News Library, UPI File (reporting results of poll finding that $54 \%$ of blacks thought criminal justice system was biased against blacks).

116. See, e.g., Claude R. Marx, How Representative Are They?, INVESTOR's Bus. DaILY, Aug. 10, 1994, at 1 (noting Time-CNN poll that "indicated [that] 25\% of all blacks believe crime is the nation's most important problem while $19 \%$ of the general population believes that," and Gallup Poll that "indicate[d] that $94 \%$ of blacks consider crime a very important problem, while $85 \%$ of whites did [sic]").

117. The victimization rate of blacks is higher than that of any other racial group for almost all crimes, including murder, rape, robbery, aggravated assault, and larceny. See STATISTICAL ABSTRACT 1994, supra note 13, at 201, 203 (giving figures for 1992).

118. See Marx, supra note 116, at 1 (reporting poll conducted by Joint Center for Political and Economic Studies indicating that $48 \%$ of blacks support capital punishment, compared to $70 \%$ of general public).

119. See, e.g., Ronald Brownstein. Clinton's "New Democrat" Agenda Reopens Racial Divisions; President's Ideas on Crime and Welfare Don't Sit Well With Blacks In Congress. Liberals' Dissatisfaction May Be Rising, L.A. TIMES, Feb. 9, 1994, at A5 (reporting that $43 \%$ of blacks, but only $18 \%$ of whites, said that tougher crime measures would be enforced in discriminatory fashion). The Crime Bill of 1994 can be found at Violent Crime Control and Law Enforcement Act of 1994, Pub. L. No. 103-322, 108 Stat. 1796 (1995). 
community, the polls, along with significant evidence from popular culture, ${ }^{120}$ suggest that a substantial portion of the African-American community sympathizes with racial critiques of the criminal justice system.

African-American jurors who endorse these critiques are in a unique position to act on their beliefs when they sit in judgment of a black defendant. As jurors, they have the power to convict the defendant or to set him free. May the responsible exercise of that power include voting to free a black defendant who the juror believes is guilty? The next section suggests that, based on legal doctrine concerning the role of juries in general, and the role of black jurors in particular, the answer to this question is "yes."

\section{B. Jury Nullification}

When a jury disregards evidence presented at trial and acquits an otherwise guilty defendant, because the jury objects to the law that the defendant violated or to the application of the law to that defendant, it has practiced jury nullification. In this section, I describe the evolution of this doctrine and consider its applicability to African-Americans. I then examine Supreme Court cases that discuss the role of black people on juries. In light of judicial rulings in these areas, I argue that it is both lawful and morally right that black jurors consider race in reaching verdicts in criminal cases.

\section{What Is Jury Nullification?}

Jury nullification occurs when a jury acquits a defendant who it believes is guilty of the crime with which he is charged. In finding the defendant not guilty, the jury refuses to be bound by the facts of the case or the judge's instructions regarding the law. Instead, the jury votes its conscience.

In the United States, the doctrine of jury nullification originally was based on the common law idea that the function of a jury was, broadly, to decide

120. See Kennedy, supra note 83 , at $1258 \mathrm{n} .10$, on the role of rap musicians in publicizing racial critiques. Other examples of racial critiques abound in black popular culture. In literature, see, for example, Nathan MCCAll, Makes Me Wanna Holler (1994), Alice Walker, The Color PURPLe (1982), and RICHARD WRIGHT, NATIVE SON (1940). In film, see, for example, Ernest Dickerson's JUICE (Paramount Pictures 1992), Spike Lee's Do THE RIGHT THING (Universal Studios 1989) and MALCOLM X (Warner Brothers 1992), and John Singleton's BOYZ N THE HOOD (Columbia Pictures 1991). In art, see, for example, JACOB LAWRENCE, Panel Number 22, in THE MIGRATION SERIES (1940-41) (depicting three black men, handcuffed together, facing columns that look like prison bars, and accompanied by text stating: "Migrants left. They did not feel safe. It was not wise to be found on the streets late at night. They were arrested on the slightest provocation."). See generally THELMA GOLDEN, BLACK MALE: REPRESENTATIONS OF MASCULINITY IN CONTEMPORARY AMERICAN ART (1994) (catalog from exhibit at Whitney Museum of American Art). 
justice, which included judging the law as well as the facts. ${ }^{121}$ If jurors believed that applying a law would lead to an unjust conviction, they were not compelled to convict someone who had broken that law. ${ }^{122}$ Although most American courts now disapprove of a jury's deciding anything other than the "facts," the Double Jeopardy Clause of the Fifth Amendment prohibits appellate reversal of a jury's decision to acquit, regardless of the reason for the acquittal. ${ }^{123}$ Thus, even when a trial judge thinks that a jury's acquittal directly contradicts the evidence, the jury's verdict must be accepted as final. ${ }^{124}$ The jurors, in judging the law, function as an important and necessary check on government power. ${ }^{125}$

\section{A Brief History}

The prerogative of juries to nullify has been part of English and American law for centuries. In 1670, the landmark decision in Bushell's Case ${ }^{126}$ established the right of juries under English common law to nullify on the basis of an objection to the law the defendant had violated. Two members of an unpopular minority group-the Quakers-were prosecuted for unlawful assembly and disturbance of the peace. At trial, the defendants, William Penn and William Mead, admitted that they had assembled a large crowd on the streets of London. Upon that admission, the judge asked the men if they wished to plead guilty. Penn replied that the issue was not " "whether I am guilty of this Indictment but whether this Indictment be legal,""127 and argued that the jurors should go "behind" the law and use their consciences to decide whether he was guilty. ${ }^{128}$ The judge disagreed, and he instructed the jurors that the defendants' admissions compelled a guilty verdict. After extended deliberation, however, the jurors found both defendants not guilty. The judge then fined the jurors for rendering a decision contrary to the evidence and to his instructions. When one juror, Bushell, refused to pay his fine, the issue reached the Court of Common Pleas, which held that jurors in criminal cases could not be punished for voting to acquit, even when the trial judge believed

121. See JEFFREY ABRAMSON, WE, THE JURY: THE JURY SYSTEM AND THE IDEAL OF DEMOCRACY 61 (1994).

122. Id.

123. United States v. Scott, 437 U.S. 82,91 (1978) ("To permit a second trial after an acquittal, however mistaken the acquittal may have been, would present an unacceptably high risk that the Government, with its vastly superior resources, might wear down the defendant so that "even though innocent, he may be found guilty."' (quoting Green v. United States, 355 U.S. 184, 188 (1957))); United States v. Ball, 163 U.S. 662, 671 (1896) ("II]n this country a verdict of acquittal, although not followed by any judgment, is a bar to a subsequent prosecution for the same offense.").

124. "[A] jury verdict of not guilty is not subject to reversal or to review in any manner whatsoever." Wayne R. LAFAVe \& Jerold H. ISRAel, Criminal Procedure $§ 22.1$ (g) (2d ed. 1992).

125. See infra note 151 and accompanying text.

126. 124 Eng. Rep. 1006 (C.P. 1670).

127. ABRAMSON, supra note 121, at 69 (quoting from 6 Howell's State Trials 958 (1670)).

128. Id. at 70 (citing 6 Howell's State Trials at 959-60). 
that the verdict contradicted the evidence. The reason was stated by the Chief Justice of the Court of Common Pleas:

A man cannot see by anothers eye, nor hear by anothers ear, no more can a man conclude or inferr the thing to be resolv'd by anothers understanding or reasoning; and though the verdict be right the jury give, yet they being not assur'd it is so from their own understanding, are forsworn, at least in foro conscientiae. ${ }^{29}$

This decision "changed the course of jury history."130 It is unclear why the jurors acquitted Penn and Mead, but their act has been viewed in near mythological terms. Bushell and his fellow jurors have come to be seen as representing the best ideals of democracy because they "rebuffed the tyranny of the judiciary and vindicated their own true historical and moral purpose." $" 131$

American colonial law incorporated the common law prerogative of jurors to vote according to their consciences after the British government began prosecuting American revolutionaries for political crimes. ${ }^{132}$ The best known of these cases involved John Peter Zenger, who was accused of seditious libel for publishing statements critical of British colonial rule in North America. ${ }^{133}$ In seditious libel cases, English law required that the judge determine whether the statements made by the defendant were libelous; the jury was not supposed to question the judge's finding on this issue. At trial, Zenger's attorney told the jury that it should ignore the judge's instructions that Zenger's remarks were libelous because the jury " $\mathrm{ha}$ [d] the right beyond all dispute to determine both the law and the facts." 134 The lawyer then echoed the language of Bushell's Case, arguing that the jurors had "to see with their eyes, to hear with their own ears, and to make use of their own consciences and understandings, in judging of the lives, liberties or estates of their fellow subjects." 135 Famously, the jury acquitted Zenger, and another case entered the canon as a shining example of the benefits of the jury system.

After Zenger's trial, the notion that juries should decide "justice," as opposed to simply applying the law to the facts, became relatively settled in

129. Bushell's Case, 124 Eng. Rep. at 1013.

130. ABRAMSON, supra note 121 , at 72 .

131. Thomas A. Green, Verdict according to Conscience: Perspectives on the English CRIMINAL TRIAL JURY, 1200-1800, at 225-26 (1985).

132. See ABRAMSON, supra note 121 , at 68 .

133. See id. at 73-75 (citing 17 Howell's State Trials 675 (1735)).

134. Philip B. Scott, Jury Nullification: An Historical Perspective on a Modern Debate, 91 W. VA. L. REV. 389, 414 (1989), quoted in M. Kristine Creagan, Jury Nullification: Assessing Recent Legislative Developments, 43 CASE W. RES. L. REV. 1101, 1109 (1993).

135. James Alexander, A Brief NarRative of the Case and Trial of John PETer Zenger PRINTER OF THE NEW YORK WEEKLY JOURNAL 93 (Stanley N. Katz ed., 1963) (1736). 
American jurisprudence. ${ }^{136}$ In addition to pointing to political prosecutions of white American revolutionaries like Zenger, modern courts and legal historians often cite with approval nullification in trials of defendants "guilty" of helping to free black slaves. ${ }^{137}$ In these cases, Northern jurors with abolitionist sentiments used their power as jurors to subvert federal law that supported slavery. In United States $v$. Morris ${ }^{138}$ for example, three defendants were accused of aiding and abetting a runaway slave's escape to Canada. The defense attorney told the jury that, because it was hearing a criminal case, it had the right to judge the law, and if it believed that the Fugitive Slave Act was unconstitutional, it was bound to disregard any contrary instructions given by the judge. ${ }^{139}$ The defendants were acquitted, and the government dropped the charges against five other people accused of the same crime. ${ }^{140}$ Another success story entered the canon.

\section{Sparf and Other Critiques}

In the mid-nineteenth century, as memories of the tyranny of British rule faded, some American courts began to criticize the idea of jurors deciding justice. ${ }^{141}$ A number of the state decisions that allowed this practice were overruled, ${ }^{142}$ and in the 1895 case of Sparf v. United States, ${ }^{143}$ the Supreme Court spoke regarding jury nullification in federal courts.

In Sparf, two men on trial for murder requested that the judge instruct the jury that it had the option of convicting them of manslaughter, a lesserincluded offense. The trial court refused this request and instead instructed the jurors that if they convicted the defendants of any crime less than murder, or if they acquitted them, the jurors would be in violation of their legal oath and duties. The Supreme Court held that this instruction was not contrary to law and affirmed the defendants' murder convictions. The Court acknowledged that juries have the "physical power" to disregard the law, but stated that they

136. See United States v. Dougherty, 473 F.2d 1113, 1130 (D.C. Cir. 1972) ("The pages of history shine on instances of the jury's exercise of its prerogative to disregard uncontradicted evidence and instructions of the judge."); Creagan, supra note 134, at 1109 ("Every jurisdiction which confronted the issue of the jury's right to decide the law as well as the facts reached the same conclusion: American juries had the right to decide the law.").

137. See, e.g., Dougherty, 473 F.2d at 1130; ABRAMSON, supra note 121, at 80-85. The Fugitive Slave Law of 1850 granted the slaveowner authority to remove a slave from a free state upon presenting "satisfactory proof" of ownership in an ex parte proceeding before a federal magistrate. Id. at 80 . Although the Fugitive Slave Law sought to avoid jury trials, those arrested and charged for aiding the escape of fugitive slaves were often tried before juries. Id.

138. 26 F. Cas. 1323 (C.C.D. Mass. 1851) (No. 15,815).

139. See id. at 1331 .

140. See AbRAMSON, supra note 121, at 82 (citing Morris, 26 F. Cas. 1323).

141. See id. at 75 .

142. Id.

143. 156 U.S. 51 (1895). 
have no "moral right" to do so. ${ }^{144}$ Indeed, the Court observed, "If the jury were at liberty to settle the law for themselves, the effect would be ... that the law itself would be most uncertain, from the different views, which different juries might take of it." ${ }^{145}$ Despite this criticism, Sparf conceded that, as a matter of law, a judge could not prevent jury nullification, because in criminal cases "“[a] verdict of acquittal cannot be set aside." "146 An anomaly was thus created, and has been a feature of American criminal law ever since: Jurors have the power to nullify, but, in most jurisdictions, they have no right to be informed of this power. ${ }^{147}$

Since Sparf, most of the appellate courts that have considered jury nullification have addressed that anomaly and have endorsed it. ${ }^{148}$ Some of these courts, however, have not been as critical of the concept of jury nullification as the Sparf Court. ${ }^{149}$ The D.C. Circuit's opinion in United States v. Dougherty ${ }^{150}$ is illustrative. In Dougherty, the court noted that the ability of juries to nullify was widely recognized and even approved "as a 'necessary counter to case-hardened judges and arbitrary prosecutors."'151 This necessity, however, did not establish "as an imperative" that a jury be informed by the judge of its power to nullify. ${ }^{152}$ The D.C. Circuit was concerned that "[w] hat makes for health as an occasional medicine would be disastrous as a daily diet." ${ }^{153}$ Specifically:

Rules of law or justice involve choice of values and ordering of objectives for which unanimity is unlikely in any society, or group representing the society, especially a society as diverse in cultures and interests as ours. To seek unity out of diversity, under the national motto, there must be a procedure for decision by vote of a majority or prescribed plurality - in accordance with democratic philosophy. To assign the role of mini-legislature to the various petit juries, who must hang if not unanimous, exposes criminal law and administration to

144. Id. at 74 (quoting United States v. Battiste, 24 F. Cas. 1042, 1043 (C.C.D. Mass. 1835) (No. 14,545)).

145. Id. (quoting Battiste, 24 F. Cas. at 1043).

146. Id. at 106 (quoting United States v. Taylor, 11 F. 470,474 (C.C.D. Kan. 1882)).

147. The constitutions of Indiana and Maryland, however, state that juries shall be the judges of both the law and the facts, see IND. CONST. art. I, § 19; MD. CONST. (DECL. OF RIGHTS) art. XXIII, and may thus permit jurors hearing criminal cases to be instructed on their prerogative to nullify, see Clark v. State, 561 N.E.2d 759 (Ind. 1990) (upholding jury instructions that indicated that jurors could determine law as well as facts); Stevenson v. State, 423 A.2d 558 (Md. 1980) (supporting contention that juries can judge law, in accordance with Declaration of Rights in Maryland Constitution, but confining that right to resolving conflicting interpretations of criminal statute and deciding whether to apply law to questionable fact patterns).

148. See ABRAMSON, supra note 121 , at 63 .

149. Id. at 62 .

150. 473 F.2d 1113 (D.C. Cir. 1972).

151. Id. at 1176 (quoting Abe Fortas in Follow-Up/The Jury, CENTER, July/Aug. 1970, at 59, 61).

152. Dougherty, 473 F.2d at 1176.

153. Id. 
paralysis, and to a deadlock that betrays rather than furthers the assumptions of viable democracy. ${ }^{154}$

The idea that jury nullification undermines the rule of law is the most common criticism of the doctrine. The concern is that the meaning of selfgovernment is threatened when twelve individuals on a jury in essence remake the criminal law after it has already been made in accordance with traditional democratic principles. Another critique of African-American jurors engaging in racially based jury nullification is that the practice by black jurors is distinct from the historically approved cases because the black jurors are not so much "judging" the law as preventing its application to members of their own race. The reader should recognize that these are moral, not legal, critiques because, as discussed above, the legal prerogative of any juror to acquit is well established. In the next section, I respond to these moral critiques.

\section{The Moral Case for Jury Nullification by African-Americans}

Any juror legally may vote for nullification in any case, but, certainly, jurors should not do so without some principled basis. The reason that some historical examples of nullification are viewed approvingly is that most of us now believe that the jurors in those cases did the morally right thing; it would have been unconscionable, for example, to punish those slaves who committed the crime of escaping to the North for their freedom. It is true that nullification later would be used as a means of racial subordination by some Southern jurors, ${ }^{155}$ but that does not mean that nullification in the approved cases was wrong. It only means that those Southern jurors erred in their calculus of justice. I distinguish racially based nullification by African-Americans from recent right-wing proposals for jury nullification ${ }^{156}$ on the ground that the former is sometimes morally right and the latter is not.

The question of how to assign the power of moral choice is a difficult one. Yet we should not allow that difficulty to obscure the fact that legal resolutions involve moral decisions, judgments of right and wrong. The fullness of time permits us to judge the fugitive slave case differently than the Southern pro-white-violence case. One day we will be able to distinguish between racially based nullification and that proposed by certain right-wing activist groups. ${ }^{157} \mathrm{We}$ should remember that the morality of the historically approved cases was not so clear when those brave jurors acted. After all, the fugitive slave law was enacted through the democratic process, and those jurors who disregarded it subverted the rule of law. Presumably, they were

154. Id.

155. See supra note 11.

156. See supra note 11.

157. See supra note 11 . 
harshly criticized by those whose interests the slave law protected. Then, as now, it is difficult to see the picture when you are inside the frame.

In this section, I explain why African-Americans have the moral right to practice nullification in particular cases. ${ }^{158} \mathrm{I}$ do so by responding to the traditional moral critiques of jury nullification.

\section{African-Americans and the "Betrayal" of Democracy}

There is no question that jury nullification is subversive of the rule of law. It appears to be the antithesis of the view that courts apply settled, standing laws and do not "dispense justice in some ad hoc, case-by-case basis." 159 To borrow a phrase from the D.C. Circuit, jury nullification "betrays rather than furthers the assumptions of viable democracy." ${ }^{160}$ Because the Double Jeopardy Clause makes this power part-and-parcel of the jury system, the issue becomes whether black jurors have any moral right to "betray democracy" in this sense. I believe that they do for two reasons that I borrow from the jurisprudence of legal realism and critical race theory: First, the idea of "the rule of law" is more mythological than real, and second, "democracy," as practiced in the United States, has betrayed African-Americans far more than they could ever betray it. Explication of these theories has consumed legal scholars for years, and is well beyond the scope of this Essay. I describe the theories below not to persuade the reader of their rightness, but rather to make the case that a reasonable juror might hold such beliefs, and thus be morally justified in subverting democracy through nullification.

\section{The Rule of Law as Myth}

The idea that "any result can be derived from the preexisting legal doctrine" either in every case or many cases, ${ }^{161}$ is a fundamental principle of legal realism (and, now, critical legal theory). The argument, in brief, is that

158. This section illustrates why my argument is about race rather than class, even though the criminal justice system may oppress poor white people as well as African-Americans. Were I concerned about social change to the exclusion of morality, I would also encourage white jurors to engage in nullification in some cases with white defendants, for white nullification would more quickly achieve my goal of the subversion of the present criminal justice system. As I noted earlier, however, my focus is on black power; the moral case $I$ make is limited to African-Americans, based on their unique history and position in the United States. Indeed, some of my analysis would not justify nullification by whites. My response to the betrayingdemocracy critique, for example, argues that black juror nullification is morally justifiable because, in American democracy, African-Americans suffer the tyranny of the majority. See infra Subsection II.C.4. This argument would not apply to white people, not even to poor whites, because they are part of the majority.

159. Michael S. Moore, A Natural Law Theory of Interpretation, 58 S. CAL. L. REV. 277, 313 (1985).

160. United States v. Dougherty, 473 F.2d 1113, 1136 (D.C. Cir. 1972).

161. See Lawrence B. Solum, On the Indeterminacy Crisis: Critiquing Critical Dogma, 54 U. CHI. L. REV. 462, 470 (1987) (describing "indeterminacy thesis"). 
law is indeterminate and incapable of neutral interpretation. ${ }^{162}$ When judges "decide" cases, they "choose" legal principles to determine particular outcomes. Even if a judge wants to be neutral, she cannot, because, ultimately, she is vulnerable to an array of personal and cultural biases and influences; she is only human. In an implicit endorsement of the doctrine of jury nullification, legal realists also suggest that, even if neutrality were possible, it would not be desirable, because no general principle of law can lead to justice in every case. $^{163}$

It is difficult for an African-American knowledgeable of the history of her people in the United States not to profess, at minimum, sympathy for legal realism. ${ }^{164}$ Most blacks are aware of countless historical examples in which African-Americans were not afforded the benefit of the rule of law: Think, for example, of the existence of slavery in a republic purportedly dedicated to the proposition that all men are created equal, or the law's support of statesponsored segregation even after the Fourteenth Amendment guaranteed blacks equal protection. That the rule of law ultimately corrected some of the large holes in the American fabric is evidence more of its malleability than of its virtue; the rule of law had, in the first instance, justified the holes. ${ }^{165}$

The Supreme Court's decisions in the major "race" cases of the last term underscore the continuing failure of the rule of law to protect AfricanAmericans through consistent application. Dissenting in a school desegregation case, ${ }^{166}$ four Justices stated that " $[t]$ he Court's process of orderly adjudication has broken down in this case." 167 The dissent noted that the majority opinion "effectively . . overrule[d] a unanimous constitutional precedent of 20 years standing, which was not even addressed in argument, was mentioned merely in passing by one of the parties, and discussed by another of them only in a misleading way." ${ }^{168}$ Similarly, in a voting rights case, ${ }^{169}$ Justice Stevens,

162. See generally ROBERTO M. UNGER, KNOWLEDGE \& POLITICs (1975) (arguing that perceptions of knowledge and reality are reciprocally dependant on political viewpoints).

163. See, e.g., Jerome Frank, Are Judges Human?, 80 U. PA. L. REv. 17, $23-24$ (1931) (discussing uncertainty of legal rules).

164. See A. LeON Higginbotham, JR., IN THE MatTER OF COLOR: RACE AND THE AMERICAN LEGAL PROCESS 3-16 (1978) (describing discrimination by legal system against African-Americans throughout American history and consequent skepticism towards equality of "rule of law").

165. See, e.g., Plessy v. Ferguson, 163 U.S. 537 (1896) (holding that racial segregation in public transportation, mandated by legislation, does not violate Equal Protection Clause of Fourteenth Amendment, and rejecting argument that such racial separation treats African-Americans as inferior); Dred Scott v. Sandford, 60 U.S. (19 How.) 393, 404-07 (1857) (declaring that slaves were not "citizens" within meaning of Constitution because at time of framing of Constitution they had been "considered . . . a subordinate and inferior class of beings, who had been subjugated by the dominant race, and, whether emancipated or not, yet remained subject to their authority" and were "so far inferior, that they had no rights which the white man was bound to respect").

166. Missouri v. Jenkins, 115 S. Ct. 2038 (1995) (holding that district court order to attract nonminority students to school district in furtherance of interdistrict goal was beyond scope of court's authority).

167. Id. at 2073 (Souter, J., dissenting).

168. Id. at 2074 (Souter, J., dissenting). 
in dissent, described the majority opinion as a "law-changing decision." 170 And in an affirmative action case, ${ }^{171}$ Justice Stevens began his dissent by declaring that, "[i]nstead of deciding this case in accordance with controlling precedent, the Court today delivers a disconcerting lecture about the evils of governmental racial classifications." 172 At the end of his dissent, Stevens argued that "the majority's concept of stare decisis ignores the force of binding precedent." $" 173$

If the rule of law is a myth, or at least is not applicable to AfricanAmericans, the criticism that jury nullification undermines it loses force. The black juror is simply another actor in the system, using her power to fashion a particular outcome; the juror's act of nullification-like the act of the citizen who dials 911 to report Ricky but not Bob, or the police officer who arrests Lisa but not Mary, or the prosecutor who charges Kwame but not Brad, or the judge who finds that Nancy was illegally entrapped but Verna was not-exposes the indeterminacy of law, but does not create it.

\section{The Moral Obligation to Disobey Unjust Laws}

For the reader who is unwilling to concede the mythology of the rule of law, I offer another response to the concern about violating it. Assuming, for the purposes of argument, that the rule of law exists, there still is no moral obligation to follow an unjust law. ${ }^{174}$ This principle is familiar to many African-Americans who practiced civil disobedience during the civil rights protests of the 1950s and 1960s. Indeed, Martin Luther King suggested that

169. Miller v. Johnson, $115 \mathrm{~S}$. Ct. 2475 (1995) (affirming holding, in case brought by white constituents claiming vote dilution, that Georgia's congressional redistricting plan violated Equal Protection Clause, in part because of its allegedly racial rationale).

170. Id. at 2497 (Stevens, J., dissenting).

171. Adarand Constructors v. Pena, 115 S. Ct. 2097 (1995) (holding that racial classifications imposed by government actors must withstand strict scrutiny).

172. Id. at 2120 (Stevens, J., dissenting).

173. Id. at 2131 (Stevens, J., dissenting).

174. The moral responsibility to obey the criminal law sometimes is premised on the duty of fair play. Herbert Morris writes, for example:

[I]t is just to punish those who have violated the rules and caused the unfair distribution of benefits and burdens. A person who violates the rules has something others have-the benefits of the system-but by renouncing what others have assumed, the burdens of self-restraint, he has acquired an unfair advantage.

Herbert MORRIS, Persons and Punishment, in ON GUILT AND InNOCENCE: EsSAYS IN LEgal PHILOSOPHY AND MORAL PSYCHOLOGY 31, 34 (1976). What if, as racial critics argue, the African-American who violates the rules does not have the benefits of the system? The logical inference is that punishment is unjust. Related arguments may be made with regard to other theories of the obligation to obey. The "natural duties" theory, in brief, suggests that there is a natural duty to support just institutions. See JoHN RAWLS, A THEORY OF JUSTICE 114-17 (1971). Again, if the criminal law is unjust, there is no duty to support it. Finally, the "social contract" theory assumes that people have, explicitly or implicitly, consented to obey the law. See Kent Greenawalt, The Natural Duty to Obey the Law, 84 MiCH. L. REV. 1, 5 (1985). The radical critic's response to social contract theory is that African-Americans were not consulted, explicitly or implicitly. Cf. id. (arguing for "implausibility of claims of general consent"). 
morality requires that unjust laws not be obeyed. ${ }^{175}$ As I state above, ${ }^{176}$ the difficulty of determining which laws are unjust should not obscure the need to make that determination.

Radical critics believe that the criminal law is unjust when applied to some antisocial conduct by African-Americans: The law uses punishment to treat social problems that are the result of racism and that should be addressed by other means such as medical care or the redistribution of wealth. Later, I suggest a utilitarian justification for why African-Americans should obey most criminal law: It protects them. ${ }^{177}$ I concede, however, that this limitation is not morally required if one accepts the radical critique, which applies to all criminal law.

\section{Democratic Domination}

Related to the "undermining the law" critique is the charge that jury nullification is antidemocratic. The trial judge in the Barry case, for example, in remarks made after the conclusion of the trial, expressed this criticism of the jury's verdict: “"The jury is not a mini-democracy, or a mini-legislature . . . . They are not to go back and do right as they see fit. That's anarchy. They are supposed to follow the law." 178 A jury that nullifies "betrays rather than furthers the assumptions of viable democracy." In a sense, the argument suggests that the jurors are not playing fair: The citizenry made the rules, so the jurors, as citizens, ought to follow them.

What does "viable democracy" assume about the power of an unpopular minority group to make the laws that affect them? It assumes that the group has the power to influence legislation. The American majority-rule electoral system is premised on the hope that the majority will not tyrannize the minority, but rather represent the minority's interests. Indeed, in creating the Constitution, the Framers attempted to guard against the oppression of the minority by the majority. ${ }^{179}$ Unfortunately, these attempts were expressed

175. See Martin L. KING, JR., Letter From a Birmingham Jail, in Why We CAN'T Wait 77, 84 (1964) ("[O]ne has a moral responsibility to disobey unjust laws. I would agree with St. Augustine that "an unjust law is no law at all.'"). In opposition to my views, however, King believed that one who breaks an unjust law must do so "with a willingness to accept the penalty." Id. at 86 . This view is also contrary to the view of the morality of nullification in the historically approved cases; few people argue, for example, that the runaway slaves should have been willing to accept the penalty when they broke unjust laws.

176. See supra text accompanying notes $155-58$.

177. For a summary, and critique, of utilitarian justifications for obeying the law, see Greenawalt, supra note 174 , at $5-6$. DI. D3.

178. Barton Gellman, Barry Judge's Remarks Break Judicial Norms, WASH. POST, Nov. 2, 1990, at

179. In his celebrated discussion of the dangers of faction in The Federalist No. 10, James Madison stated that, to prevent a majority faction from sacrificing the "public good and the rights of other citizens" to "its own ruling passion," the existence of the passion must be prevented or the majority "must be rendered, by their number and local situation, unable to concert and carry into effect schemes of oppression." THE Federalist No. 10, at 80-81 (James Madison) (Clinton Rossiter ed., 1961); see also Alexander Hamilton, Debate of Monday, June 18, 1787, in 5 DEBATES ON THE ADOPTION OF THE FEDERAL 
more in theory than in actual constitutional guarantees, a point made by some legal scholars, particularly critical race theorists.

The implication of the failure to protect blacks from the tyrannical majority is that the majority rule of whites over African-Americans is, morally speaking, illegitimate. Lani Guinier suggests that the moral legitimacy of majority rule hinges on two assumptions: 1) that majorities are not fixed; and 2) that minorities will be able to become members of some majorities. ${ }^{180}$ Racial prejudice "to such a degree that the majority consistently excludes the minority, or refuses to inform itself about the relative merit of the minority's preferences," defeats both assumptions. ${ }^{181}$ Similarly, Owen Fiss has given three reasons for the failure of blacks to prosper through American democracy: They are a numerical minority, they have low economic status, and, "as a 'discrete and insular' minority, they are the object of 'prejudice'- that is, the subject of fear, hatred, and distaste that make it particularly difficult for them to form coalitions with others (such as the white poor)."182

According to both theories, blacks are unable to achieve substantial progress through regular electoral politics. ${ }^{183}$ Their only "democratic" route to success-coalition building with similarly situated groups-is blocked because other groups resist the stigma of the association. The stigma is powerful enough to prevent alignment with African-Americans even when a group-like low income whites-has similar interests.

In addition to individual white citizens, legislative bodies experience the Negrophobia described above. Professor Guinier defines such legislative racism as

a pattern of actions [that] persistently disadvantag[es] a fixed, legislative minority and encompasses conscious exclusion as well as marginalization that results from "a lack of interracial empathy." It means that where a prejudiced majority rules, its representatives are

Constitution in the Convention Held at Philadelphia IN 1787, at 198, 203 (reprint, Ayer Co. 1987) (Jonathan Elliot ed., New York 1888) ("Give all power to the many, they will oppress the few. Give all power to the few, they will oppress the many. Both, therefore, ought to have the power, that each may defend itself against the other."). This concern was not limited to the Framers; John Stuart Mill, for example, shared it. See JOHN STUART MILL, ON LIBERTY 7 (Currin V. Shields ed., Liberal Arts Press 1956) (1859) ("'[T]he tyranny of the majority" is now generally included among the evils against which society requires to be on its guard.").

180. See Lani Guinier, No Two Seats: The Elusive Quest For Political Equality, 77 VA. L. Rev. 1413, 1479 (1991).

I81. Id. at $1478-79$.

182. Owen M. Fiss, Groups and the Equal Protection Clause, 5 PHIL. \& PuB. AfF. 107, 152 (1976).

183. This is exemplified by the abject failure of the Congressional Black Caucus's effort to amend the Crime Bill of 1994. See Derrick Z. Jackson, Equal Justice Takes A Loss, BosToN GLoBE, Aug. 3, 1994, at 15. The proposed change would have amended Part VI of Title 28 of the United States Code to prohibit capital sentences from being imposed on the basis of race and to allow statistics regarding racial discrimination to be introduced in death penalty cases. See H.R. 4017, 103d Cong., 2d Sess. \$ 2(a) (1994). Ironically, it was called the "Racial Justice Act." Id. \$1. This episode seems to demonstrate the inadequacy of the argument that white legislators will adequately represent black interests. 
not compelled to identify its interests with those of the AfricanAmerican minority. ${ }^{184}$

Such racism excludes blacks from the governing legislative coalitions. A permanent, homogeneous majority emerges, which effectively marginalizes minority interests and "transform[s] majority rule into majority tyranny."185 Derrick Bell calls this condition "democratic domination."186

Democratic domination undermines the basis of political stability, which depends on the inducement of "losers to continue to play the political game, to continue to work within the system rather than to try to overthrow it."187 Resistance by minorities to the operation of majority rule may take several forms, including "overt compliance and secret rejection of the legitimacy of the political order." 188 I suggest that another form of this resistance is racially based jury nullification.

If African-Americans believe that democratic domination exists (and the 1994 congressional elections seem to provide compelling recent support for such a belief ${ }^{189}$ ), they should not back away from lawful self-help measures, like jury nullification, on the ground that the self-help is antidemocratic. ${ }^{190}$ African-Americans are not a numerical majority in any of the fifty states, which are the primary sources of criminal law. ${ }^{191}$ In addition, they are not even proportionally represented in the U.S. House of Representatives or in the

184. Guinier, supra note 180 , at $1444-45$.

185. Id. at 1479.

186. BELL, supra note 83, at 177.

187. Nicholas R. Miller, Pluralism and Social Choice, 77 AM. PoL. SCI. REv. 734, 742 (1983).

188. RoBert A. DAHL, A PREFACE to DEMOCRATIC THEORY 97-98 (1956).

189. Among white men, $66 \%$ voted a straight Republican ticket during the 1994 congressional elections. See Donald Lambro, GOP Eyes Extended Political Control, WASH. TimES, Feb. 26, 1995, at A4. Sixty percent of white female homemakers and nearly $50 \%$ of white working women did the same. Id. Seventy-eight percent of white men, $68 \%$ of white working women, and $66 \%$ of white female homemakers stated a desire for "more conservative policies and programs." Id.

190. The "betraying democracy" critique might be more persuasive when it is applied to groups, like poor or "ethnic" whites, that have more influence over the law (because the stigma of coalition building with African-Americans is not present), which is one reason why I believe that the justification for the type of jury nullification I propose is rooted more in race subordination than class subordination. Some Marxists argue, however, that criminal punishment is unfair when it occurs in a society characterized by extreme social and class stratification. See, e.g., Jeffrie G. Murphy, Marxism and Retribution, 2 PHIL. \& PUB. AFF. 217 (1973).

191. Even in the District of Columbia, where blacks are a majority, the U.S. Congress may veto any local law passed by the city's elected representatives. One telling example of democratic domination involved D.C.'s sodomy law. In the early 1980s, the locally elected city council repealed the law criminalizing consensual sodomy. See Rene Sanchez, D.C. Sodomy Law Is Off the Books: Congress Allows Repeal, Ending 12-Year Battle by Gay-Rights Advocates, WASH. POST, Sept. 18, 1993, at B3. In response, Congress overturned the city council's action and reinstated sodomy as a crime. See id. In 1993, the city council again repealed the law, but this time Congress allowed the local legislature's action to stand. See id. 
Senate. ${ }^{192}$ As a result, African-Americans wield little influence over criminal law, state or federal. African-Americans should embrace the antidemocratic nature of jury nullification because it provides them with the power to determine justice in a way that majority rule does not.

\section{D. "[J]ustice must satisfy the appearance of justice":193 The Symbolic Function of Black Jurors}

A second distinction one might draw between the traditionally approved examples of jury nullification and its practice by contemporary AfricanAmericans is that, in the case of the former, jurors refused to apply a particular law, e.g., a fugitive slave law, on the grounds that it was unfair, while in the case of the latter, jurors are not so much judging discrete statutes as they are refusing to apply those statutes to members of their own race. This application of race consciousness by jurors may appear to be antithetical to the American ideal of equality under the law.

This critique, however, like the "betraying democracy" critique, begs the question of whether the ideal actually applies to African-Americans. As stated above, racial critics answer this question in the negative. ${ }^{194}$ They, especially the liberal critics, argue that the criminal law is applied in a discriminatory fashion. ${ }^{195}$ Furthermore, on several occasions, the Supreme Court has referred to the usefulness of black jurors to the rule of law in the United States. ${ }^{196}$ In essence, black jurors symbolize the fairness and impartiality of the law. Here I examine this rhetoric and suggest that, if the presence of black jurors sends a political message, it is right that these jurors use their power to control or negate the meaning of that message.

As a result of the ugly history of discrimination against African-Americans in the criminal justice system, ${ }^{197}$ the Supreme Court has had numerous opportunities to consider the significance of black jurors. ${ }^{198}$ In so doing, the

192. There are 39 blacks in the 104th Congress (38 in the House and 1 in the Senate), representing approximately $7 \%$ of the Representatives and $1 \%$ of the Senators, despite the fact that blacks make up roughly $12 \%$ of the population. See Case of Amnesia for the High Court: Justices Seem to Forget History and Reality of Race in America, L.A. TIMES, July 2, 1995, at M4.

193. Offutt v. United States, 348 U.S. 11, 14 (1954).

194. See supra Section II.A.

195. See, e.g., KING, supra note 175 , at 86 (stating that "[s]ometimes a law is just on its face and unjust in its application").

196. See, e.g., Batson v. Kentucky, 476 U.S. 79 (1986) (holding that Equal Protection Clause forbids prosecutor from challenging potential jurors based on their race); Strauder v. West Virginia, 100 U.S. 303 (1880) (holding that trying defendant before jury from which members of defendant's race were excluded denies defendant equal protection of law).

197. See supra notes $96-109$ and accompanying text.

198. See, e.g., Georgia v. McCollum, 505 U.S. 42 (1992) (holding that Equal Protection Clause forbids defendant to exercise peremptory challenges based on race of potential jurors); Holland v. Illinois, 493 U.S. 474 (1990) (holding that white defendant has standing to raise Sixth Amendment challenge to prosecutor's use of race as basis for dismissing black potential jurors); Batson, 476 U.S. 79; Strauder, 100 U.S. 303. 
Court has suggested that these jurors perform a symbolic function, especially when they sit on cases involving African-American defendants, ${ }^{199}$ and the Court has typically made these suggestions in the form of rhetoric about the social harm caused by the exclusion of blacks from jury service. ${ }^{200} \mathrm{I}$ will refer to this role of black jurors as the "legitimization function."

The legitimization function stems from every jury's political function of providing American citizens with "the security ... that they, as jurors actual or possible, being part of the judicial system of the country can prevent its arbitrary use or abuse." ${ }^{201}$ In addition to, and perhaps more important than, seeking the truth, the purpose of the jury system is "to impress upon the criminal defendant and the community as a whole that a verdict of conviction or acquittal is given in accordance with the law by persons who are fair."202 This purpose is consistent with the original purpose of the constitutional right to a jury trial, which was "to prevent oppression by the Government."203

When blacks are excluded from juries, beyond any harm done to the juror who suffers the discrimination or to the defendant, the social injury of the exclusion is that it "undermine[s] ... public confidence-as well [it] should." ${ }^{204}$ Because the United States is both a democracy and a pluralist society, it is important that diverse groups appear to have a voice in the laws that govern them. Allowing black people to serve on juries strengthens "public respect for our criminal justice system and the rule of law."205

The Supreme Court has found that the legitimization function is particularly valuable in cases involving "race-related" crimes. ${ }^{206}$ According to the Court, in these cases, "emotions in the affected community [are] inevitably . . . heated and volatile." ${ }^{.207}$ The potential presence of black people on the jury in a "race-related" case calms the natives, which is especially important in this type of case because "[p]ublic confidence in the integrity of the criminal justice system is essential for preserving community peace."208 The very fact that a black person can be on a jury is evidence that the criminal

199. See, e.g., Batson, 476 U.S. at 87 ("The harm from discriminatory jury selection extends beyond that inflicted on the defendant and the excluded juror to touch the entire community.").

200. The Court has openly acknowledged the significance of this rhetoric, even suggesting that it plays a role in determining its holdings. For example, in Powers v. Ohio, 499 U.S. 400 (1991), the Court stated that Batson "was designed "to serve multiple ends," only one of which was to protect individual defendants from discrimination in the selection of jurors. . . Batson recognized that a prosecutor's discriminatory use of peremptory challenges harms the excluded jurors and the community at Iarge." Id. at 406 (citations omitted) (emphasis added).

201. Balzac v. Porto Rico, 258 U.S. 298, 310 (1922).

202. Powers, 499 U.S. at 413.

203. Duncan v. Louisiana, 391 U.S. 145,155 (1968)

204. Georgia v. McCollum, 505 U.S. 42,49 (1992).

205. Batson v. Kentucky, 476 U.S. 79, 99 (1986).

206. See McColltum, 505 U.S. at 49.

207. Id.

208. Id. 
justice system is one in which black people should have confidence, and one that they should respect.

But what of the black juror who endorses racial critiques of American criminal justice? Such a person holds no "confidence in the integrity of the criminal justice system." If she is cognizant of the implicit message that the Supreme Court believes her presence sends, she might not want her presence to be the vehicle for that message. Let us assume that there is a black defendant who, the evidence suggests, is guilty of the crime with which he has been charged, and a black juror who thinks that there are too many black men in prison. The black juror has two choices: She can vote for conviction, thus sending another black man to prison and implicitly allowing her presence to support public confidence in the system that puts him there, or she can vote "not guilty," thereby acquitting the defendant, or at least causing a mistrial. In choosing the latter, the juror makes a decision not to be a passive symbol of support for a system for which she has no respect. Rather than signaling her displeasure with the system by breaching "community peace," the black juror invokes the political nature of her role in the criminal justice system and votes "no." In a sense, the black juror engages in an act of civil disobedience, except that her choice is better than civil disobedience because it is lawful. ${ }^{209}$ Is the black juror's race-conscious act moral? Absolutely. It would be farcical for her to be the sole color-blind actor in the criminal process, especially when it is her blackness that advertises the system's fairness. ${ }^{210}$

At this point, every African-American should ask herself whether the operation of the criminal law in the United States advances the interests of black people. If it does not, the doctrine of jury nullification affords AfricanAmerican jurors the opportunity to control the authority of the law over some African-American criminal defendants. In essence, black people can "opt out" of American criminal law.

How far should they go? Completely to anarchy? Or is there some place between here and there, safer than both? The next part describes such a place, and how to get there.

209. I do not mean to imply that civil disobedience is "wrong" in some sense because it is illegal; indeed, its criminality is one of its advantages, because the willingness of those practicing civil disobedience to break a law and endure the consequences emphasizes the immorality of that law. I find it troubling, however, that the power of white supremacy was such that, in order to end governmentsponsored segregation in the South, so many people-black and white-had to go to jail.

210. Although the legitimization function may be an inevitable consequence of black presence on juries, my response is not that blacks should refuse to participate in juries, which would, for obvious reasons, be counterproductive. I argue, instead, that the function provides additional moral justification for nullification by black jurors: It is appropriate for blacks to control the meaning of the symbolism their presence creates. 


\section{A PROPOSAL FOR RACIALLY BASED JURY NULLIFICATION}

To allow African-American jurors to exercise their responsibility in a principled way, I make the following proposal: African-American jurors should approach their work cognizant of its political nature and their prerogative to exercise their power in the best interests of the black community. In every case, the juror should be guided by her view of what is "just." For the reasons stated in the preceding parts of this Essay, I have more faith in the average black juror's idea of justice than I do in the idea that is embodied in the "rule of law."

\section{A. A Framework for Criminal Justice in the Black Community}

In cases involving violent malum in se crimes like murder, rape, and assault, jurors should consider the case strictly on the evidence presented, and, if they have no reasonable doubt that the defendant is guilty, they should convict. For nonviolent malum in se crimes such as theft or perjury, nullification is an option that the juror should consider, although there should be no presumption in favor of it. A juror might vote for acquittal, for example, when a poor woman steals from Tiffany's, but not when the same woman steals from her next-door neighbor. Finally, in cases involving nonviolent, malum prohibitum offenses, including "victimless" crimes like narcotics offenses, there should be a presumption in favor of nullification. ${ }^{211}$

This approach seeks to incorporate the most persuasive arguments of both the racial critics and the law enforcement enthusiasts. If my model is faithfully executed, the result would be that fewer black people would go to prison; to that extent, the proposal ameliorates one of the most severe consequences of

211. For an excellent description of the folly of punishing victimless conduct, and for an argument as to why drug offenses are victimless, see Randy E. Barnett, Bad Trip: Drug Prohibition and the Weakness of Public Policy, 103 YALE LJ. 2593, 2621-25 (1994) (reviewing STEVEN B. DUKE \& ALBERT C. Gross, America's Longest War: Rethinking OUR Tragic Crusade Against Drugs (1993)). Barnett defines victimless conduct "in terms of the "harm principle': people should have the freedom to act so long as they do not harm others. Given the inherent subjectivity of 'harm,' however, the concept of victimless conduct cannot be taken to mean conduct with no adverse effects on others." Id. at 2621 . While some of the victimless criminal conduct my proposal tolerates may have an adverse effect on others, the criminal law is not the correct way, or even an effective way, to address that adverse effect.

Perhaps my argument can be appreciated more clearly in a context outside of the heated rhetoric surrounding illegal drugs. I am acutely aware, for example, of the social cost of the "victimless" conduct of cigarette smoking, including the physical injury that second-hand tobacco smoke causes many innocent victims. See Lidia Wasowicz, Second-hand Smoke Can Kill Infants, UPI, Mar. 7, 1995, available in LEXIS, News Library, UPI File. Nonetheless, it would be misguided public policy to lock up cigarette smokers; I prefer the policies of health care for curing smokers of their self-destructive conduct and education for informing people of the danger that tobacco smoke poses. While incarceration might be a stronger deterrent to tobacco smoking than is self-preservation (the design of health care) or social reprobation (one of the designs of public education), I believe, on libertarian and utilitarian grounds, that use of the criminal law would be unjust in this context. And since I endorse the radical racial critique, I also believe, here on moral and utilitarian grounds, that the criminal law is the wrong way to treat other "victimless" conduct by African-Americans. 
law enforcement in the African-American community. ${ }^{212}$ At the same time, the proposal, by punishing violent offenses and certain others, preserves any protection against harmful conduct that the law may offer potential victims. If the experienced prosecutors at the U.S. Attorney's Office are correct, some violent offenders currently receive the benefit of jury nullification, doubtless from a misguided, if well-intentioned, attempt by racial critics to make a political point. Under my proposal, violent lawbreakers would go to prison.

In the language of criminal law, the proposal adopts utilitarian justifications for punishment: deterrence and isolation. To that extent, it accepts the law enforcement enthusiasts' faith in the possibility that law can prevent crime. The proposal does not, however, judge the lawbreakers as harshly as the enthusiasts would judge them. Rather, the proposal assumes that, regardless of the reasons for their antisocial conduct, people who are violent should be separated from the community, for the sake of the nonviolent. The proposal's justifications for the separation are that the community is protected from the offender for the duration of the sentence and that the threat of punishment may discourage future offenses and offenders. I am confident that balancing the social costs and benefits of incarceration would not lead black jurors to release violent criminals simply because of race. ${ }^{213}$ While I confess agnosticism about whether the law can deter antisocial conduct, I am unwilling to experiment by abandoning any punishment premised on deterrence.

Of the remaining traditional justifications for punishment, the proposal eschews the retributive or "just deserts" theory for two reasons. First, I am persuaded by racial and other critiques of the unfairness of punishing people for "negative" reactions to racist, oppressive conditions. In fact, I sympathize with people who react "negatively" to the countless manifestations of white supremacy that black people experience daily. While my proposal does not "excuse" all antisocial conduct, it will not punish such conduct on the premise that the intent to engage in it is "evil." The antisocial conduct is no more evil than the conditions that cause it, and, accordingly, the "just deserts" of a black offender are impossible to know. And even if just deserts were susceptible to accurate measure, I would reject the idea of punishment for retribution's sake.

My argument here is that the consequences are too severe: AfricanAmericans cannot afford to lock up other African-Americans simply on account of anger. There is too little bang for the buck. Black people have a community that needs building, and children who need rescuing, and as long as a person will not hurt anyone, the community needs him there to help.

212. Drug offenders, for example, make up approximately $60 \%$ of those incarcerated in federal prisons. See Criminal Ineptitude. ECONOMIST (London), Apr. 23, 1994, at A25.

213. See Gellman \& Horwitz, supra note 8, at A1, A14 (describing then-Washington, D.C. Police Chief Isaac Fulwood as "not[ing] that most D.C. defendants and jurors are black" and "that most trials lead to conviction," and as saying that "'[t]he overwhelming majority of black people aren't going to turn anybody away for the crime of murder"'). 
Assuming that he actually will help is a gamble, but not a reckless one, for the "just" African-American community will not leave the lawbreaker be: It will, for example, encourage his education and provide his health care (including narcotics dependency treatment) and, if necessary, sue him for child support. In other words, the proposal demands of African-Americans responsible selfhelp outside of the criminal courtroom as well as inside it. ${ }^{214}$ When the

214. For example, jurors who engage in nullification might be morally obligated to participate in black self-help programs, such as those proposed by Louis Farrakhan at the Million Man March in Washington, D.C. Farrakhan asked the hundreds of thousands of African-American men who participated in the march to pledge to "adopt" a prison inmate, see Mark Johnson \& Gil Klein, A March for Atonement: Farrakhan Leads Pledge Against Violence Before Crowd of 400,000, RICHMOND TiMES-DISPATCH, Oct. 17, 1995, at $A 1$, as well as to take personal responsibility for reducing drug use and violent crime in the AfricanAmerican community, see Jeff Barker \& Adrianne Flynn, A "New Foundation"; 400,000 Black Men Hold Peaceful Rally at Capitol, ARIZ. Republic, Oct. 17, 1995, at A1.

In addition, the self-help I prescribe may include community enforcement of norms against antisocial conduct. For example, the security force of the Nation of Islam has successfully reduced crime in some public housing projects, including those where traditional law enforcement has not been effective. See Vernon Loeb, D.C. Hires Nation of Islam Guards for SE Complex; Public Housing Chief Cites Patrols' Success At Other Developments in Nation, WASH. POST, May 4, 1995, at C1, C4 (describing Nation of Islam patrols and quoting public housing "tenant leader" Jacqueline West: "The residents really want the Nation of Islam guards-they have good manners, they know how to talk to you. They don't need guns. I like their approach."). In fact, some observers attribute whatever influence Louis Farrakhan may wield in the African-American community to the Nation of Islam's ability to rehabilitate black criminals and protect black neighborhoods. See Charlise Lyles, Farrakhan to Address Anti-Violence Rally; The Muslim Leader Will Discuss Black-on-Black Crime, VIRGINIAN-PILOT \& LEDGER STAR, July 21, 1994, at B3 (describing Nation of Islam member's view that 'Farrakhan's reputation among most blacks rests on his success in rehabilitating black men from a life of crime and cleaning up crack-addled, crime-infested communities from Los Angeles to Washington").

Many African-Americans are already engaged in efforts to prevent crime, as an alternative or supplement to cooperation with law enforcement. See, e.g., Blacks Found Putting Focus on Self-Help, L.A. TIMES, Jan. 21, 1994, at A18 (describing various black-led, anticrime programs, including gun buy-back programs, meetings among street gang leaders to negotiate national truce, and mentoring programs); Lourdes M. Leslie, "Our Young People Are Killing Each Other": Black Pastors Aim to Ignite War an Youth Violence, ARIZ. REPUBLIC, Feb. 20, 1994, at A1 (describing black minister's efforts to prevent crime by befriending black criminals and their goal of preventing crime by increasing opportunities for legal employment); Jack Wardlaw, Black Caucus: Crime Fight Is Flawed; Preventive Steps Are Urged, NEW ORLEANS TIMES-PICAYUNE, June 23, 1994, at A24 (describing Legislative Black Caucus program for reducing crime rate, including teaching nonviolent dispute resolution to students).

There is also evidence that minority groups in other societies have perceived the need for self-help to combat antisocial conduct in their communities, and have not relied upon the majority for this protection. In some Jewish communities, for example, "criminal" problems are supposed to be resolved within the community, with the guidance of a rabbi and without resort to the criminal justice system of the larger society in which the Jewish community exists. See 18.C THE TALMUD OF BABYLONIA 112 (Jacob Neusner trans., 1992) (quoting Gittin 88B: "“R. Tarfon would say, "In any case in which you find gentile law courts, even though their law is the same as Israelite law, you may not go to them, since [the Bible] says, "These are the judgments that you shall set before them,'-before them, not before gentiles."'" (citation omitted)), cited in Michael J. Broyde, Jewish Response, 16 LOY. L.A. INT'L \& COMP. L.J. 29, 32-33 \& n.22 (1993) (giving version of passage as part of Jewish response to duty to educate, in symposium on religious law) and Izhak Englard, The Relationship Between Religion and State in Israel, in JEWISH LAW IN ANCIENT AND MODERN ISRAEL 168, 176 n.33 (Haim H. Cohn ed., 1971). In one case, after a long period of inaction by the local rabbi, a Jewish family complained to British police that their children were being abused by the babysitter, a rabbinical student. See Nira Yuval-Davis, Jewish Fundamentalism and Women's Empowerment, in REFUSING HOLY ORDERS: WOMEN AND FUNDAMENTALISM IN BRITAIN 198, 219 (1992). The family members were subsequently "denounced as 'Moysers' - 'informants' - and hounded out of their home, and their children out of their school." Id. Of course, the Talmud goes further than my modest proposal, which accepts the imposition of "outsider" (white) law in many cases. I am grateful to Courtney W. Howland for informing me of these examples from the Jewish tradition. 
community is richer, perhaps then it can afford anger.

The final traditional justification for punishment, rehabilitation, can be dealt with summarily. If rehabilitation were a meaningful option in American criminal justice, I would not endorse nullification in any case. It would be counterproductive, for utilitarian reasons: The community is better off with the antisocial person cured than sick. Unfortunately, however, rehabilitation is no longer an objective of criminal law in the United States, ${ }^{215}$ and prison appears to have an antirehabilitative effect. ${ }^{216}$ For this reason, unless a juror is provided with a specific, compelling reason to believe that a conviction would result in some useful treatment for an offender, she should not use her vote to achieve this end, because almost certainly it will not occur.

\section{B. Hypothetical Cases}

How would a juror decide individual cases under my proposal? For the purposes of the following hypothesis, let us assume criminal prosecutions in state or federal court and technically guilty African-American defendants. Easy cases under my proposal include a defendant who possessed crack cocaine, and a defendant who killed another person. The former should be acquitted, and the latter should go to prison.

The crack cocaine case is simple: Because the crime is victimless, the proposal presumes nullification. According to racial critiques, acquittal is just, due in part to the longer sentences given for crack offenses than for powder cocaine offenses. ${ }^{217}$ This case should be particularly compelling to the liberal racial critic, given the extreme disparity between crack and powder in both enforcement of the law and in actual sentencing. According to a recent study,

215. See SANFord H. Kadish \& STEPHEN J. SChulhofer, CRIMINAL LaW AND ITS PRoCesses 155 (5th ed. 1989) ("[T]he rehabilitative ideal had great influence on American penology and corrections policies. In recent years, however, its influence has gone into eclipse . . ."); Robert Blecker, Haven or Hell? Inside Lorton Central Prison: Experiences of Punishment Justified, 42 STAN. L. REV. 1149, 1149 (1990) (discussing congressional rejection of rehabilitation as justification for punishment); Toni A. Massaro, Shame, Culture, and American Criminal Law, 89 MiCH. L. REv. 1880, $1890-95$ (1991) (describing and analyzing decline of rehabilitation and rise of retribution as justifications for punishment); Michael Vitiello, Reconsidering Rehabilitation, 65 TuL. L. ReV. 1011, 1012-13 (1991) (discussing widespread rejection of rehabilitation as justification for punishment by those involved in criminal justice system); $c f$. J. Gordon Seymour, Downward Departures from the Federal Sentencing Guidelines Based on the Defendant's Drug Rehabilitative Efforts, 59 U. CHI. L. REV. 837, 841 (1992) (noting refusal of some courts to allow departures from Federal Sentencing Guidelines based on defendant's postoffense drug rehabilitation).

216. See Stephen D. Sowle, A Regime of Social Death: Criminal Punishment in the Age of Prisons, 21 N.Y.U. REV. L. \& Soc. CHANGE 497, 500 (1994-95) ("The end result is that imprisonment, even when it is being used for putatively rehabilitative ends, actually incites and encourages the very forms of criminal behavior it professes to condemn and punish.").

There is a rich tradition of literature by African-Americans detailing the destruction to the human psyche that incarceration can cause. See, e.g., ELDRIDGE CLEAVER, SOUL ON ICE (1968); GEORGE JACKSON, SOLEDAd BROTHER: THE PRISON LETTERS OF GEORGE JACKSON (1970); MCCALL, supra note 120; WALKer, supra note 120; MALCOLM X \& AleX HALEY, THE Autobiography of MalCOLM X (1964).

217. See supra note 103 . 
African-Americans make up 13\% of the nation's regular drug users, but they account for $35 \%$ of narcotics arrests, $55 \%$ of drug convictions, and $74 \%$ of those receiving prison sentences. ${ }^{218}$ Most of the people who are arrested for crack cocaine offenses are black; most arrested for powder cocaine are white. ${ }^{219}$ Under federal law, if someone possesses fifty grams of crack cocaine, the mandatory-minimum sentence is ten years; in order to receive the same sentence for powder cocaine, the defendant must possess 5000 grams. ${ }^{220}$ Given the racial consequences of this disparity, I hope that many racial critics will nullify without hesitation in these cases.

The case of the murderer is "easy" solely for the utilitarian reasons I discussed above. Although I do not believe that prison will serve any rehabilitative function for the murderer, there is a possibility that a guilty verdict will prevent another person from becoming a victim, and the juror should err on the side of that possibility. In effect, I "write off" the black person who takes a life, not for retributive reasons, but because the black community cannot afford the risks of leaving this person in its midst. Accordingly, for the sake of potential victims (given the possibility that the criminal law deters homicide), nullification is not morally justifiable here.

Difficult hypothetical cases include the ghetto drug dealer and the thief who burglarizes the home of a rich family. Under the proposal, nullification is presumed in the first case because drug distribution is a nonviolent, malum prohibitum offense. Is nullification morally justifiable here? It depends. There is no question that encouraging people to engage in self-destructive behavior is evil; the question the juror should ask herself is whether the remedy is less evil. I suspect that the usual answer would be "yes," premised on deterrence and isolation theories of punishment. Accordingly, the drug dealer would be convicted. The answer might change, however, depending on the particular facts of the case: the type of narcotic sold, the ages of the buyers, whether the dealer "marketed" the drugs to customers or whether they sought him out, whether it is a first offense, whether there is reason to believe that the drug dealer would cease this conduct if given another chance, and whether, as in the crack case, there are racial disparities in sentencing for this kind of crime. I

218. See Pierre Thomas, 1 in 3 Young Black Men in Justice System; Criminal Sentencing Policies Cited in Study, WASH. POST, Oct. 5, 1995, at A1 (describing study). This discrepancy has been noted by President Clinton, who, in a recent speech, referred to the finding that one in three African-American men is under criminal justice supervision and said that "that is a disproportionate percentage in comparison to the percentage of blacks who use dugs in our society." Rift Between Blacks, Whites "Is Tearing at the Heart of America," WASH. POST, Oct. 17, 1995, at A13 (excerpting speech by President on race relations). To my mind, the President then indicated a rudimentary sympathy for my proposal when he stated that "I would like every white person here and in America to take a moment to think how he or she would feel if one in three white men were in similar circumstances." Id.

219. See Kevin Johnson, Rioting Inmates Locked Away; Violence Follows Cocaine-Lavv Vote, USA TODAY, Oct. 23, 1995, at 2A (stating that African-Americans make up $92 \%$ of crack defendants, but only $27 \%$ of powder cocaine defendants).

220. See id.; see also supra note 103. 
recognize that, in this hypothetical, nullification carries some societal risk. The risk, however, is less consequential than with violent crimes. Furthermore, the cost to the community of imprisoning all drug dealers is great. I would allow the juror in this case more discretion.

The juror should also remember that many ghetto "drug" dealers are not African-American ${ }^{221}$ and that the state does not punish these dealersinstead, it licenses them. Liquor stores are ubiquitous on the ghetto streets of America. ${ }^{222}$ By almost every measure, alcoholism causes great injury to society, ${ }^{223}$ and yet the state does not use the criminal law to address this severe social problem. When the government tried to treat the problem of alcohol use with criminal law, during Prohibition, a violent "black" market formed. ${ }^{224}$ Even if the juror does not believe that drug dealing is a "victimless" crime, she might question why it is that of all drug dealers, many of the black capitalists are imprisoned, and many of the non-black capitalists are legally enriched. When the juror remembers that the cost to the community of having so many young men in jail means that law enforcement also is not "victimless," the juror's calculus of justice might lead her to vote for acquittal.

As for the burglar who steals from the rich family, the case is troubling, first of all, because the conduct is so clearly "wrong." As a nonviolent malum in se crime, there is no presumption in favor of nullification, though it remains an option. Here, again, the facts of the case are relevant to the juror's decision of what outcome is fair. For example, if the offense was committed to support a drug habit, I think there is a moral case to be made for nullification, at least until drug rehabilitation services are available to all.

If the burglary victim is a rich white person, the hypothetical is troubling for the additional reason that it demonstrates how a black juror's sense of justice might, in some cases, lead her to treat defendants differently based on the class and race of their victims. I expect that this distinction would occur most often in property offenses because, under the proposal, no violent

221. See, e.g., Susan Moffat, Shopkeepers Fight Back: Blacks Join With Koreans in a Battle to Rebuild Their Liquor Stores, L.A. TIMES, May 15, 1992, at D1, D3 (stating that, in Los Angeles, blacks own only a minority of liquor stores in black areas).

222. See, e.g., Courtland Milloy, Message In the Bottle Is Despair, WaSH. Post, Sept. 12, 1993, at B1 (reporting that, before riots of 1992, there were 700 liquor stores in black neighborhood of South Central Los Angeles); Yolanda Woodlee, D.C. Agrees to Curtail Liquor; Council to Impose License Moratorium in Four City Wards, WASH. POST, Feb. 3, 1994, at A1 (reporting that Washington, D.C. city council is limiting new liquor licenses because "alcohol is destroying black communities" and quoting city council member Bill Lightfoot stating that "[b]lack people are killing themselves with alcohol"').

223. See Kurt L. Schmoke, An Argument in Favor of Decriminalization, 18 HoFsTRA L. REv. 501, 521-22 (1990). Schmoke notes that alcohol plays a part in approximately 25,000 automobile fatalities annually, see id. at 521 \& n.120, that $50 \%$ of all homicides in 1980 (approximately 12,000) were attributable to alcohol use, see id. at $521 \mathrm{n.123}$, and that it is estimated that, in 1983, alcohol abuse cost the United States almost $\$ 117$ billion in lost employment, reduced productivity, and health care payments, see id. at 522 n. 125 .

224. See id. at 522-23 \& nn.131-35. 
offenders would be excused. ${ }^{225}$ In an ideal world, whether the victim is rich or poor or black or white would be irreleyant to adjudication of the defendant's culpability. In the United States, my sense is that some black jurors will believe that these factors are relevant to the calculus of justice. The rationale is implicitly premised on a critique of the legitimacy of property rights in a society marked by gross economic inequities. ${ }^{226}$ While I endorse this critique,

225. Some commentators predicted that an acquittal in the O.J. Simpson case would be evidence of racially based jury nullification, see Robert Wright, Tyson $v$. Simpson, NEw REPUBLIC, Apr. 17, 1995, at 4, 49 ("The most legitimately dispiriting thing about an acquittal [in the Simpson case] would be the spectacle of a mostly black jury failing to condemn a plainly guilty black man-more grim testament to the widening gulf between white and black America."), and others have argued, since the verdict, that this is, in fact, what happened, see, e.g., Jacob Weisberg, The Truth Card, NEW YoRK, Oct. 16, 1995, at 33, 33 (stating that it was "obvious to even the most casual of observers" that "Simpson was a brutal murderer going free, that the jury had been a terrible failure, and that there was some kind of sick moral inversion about African-Americans celebrating his acquittal as a victory"). While this Essay makes an argument for racially based jury nullification, reasonable doubt-the other legal justification for acquittal-may be racially based as well. What is reasonable to an African-American may not be reasonable to a white person.

In the Simpson case, for example, police detective Mark Fuhrman claimed that he discovered an extremely incriminating item of evidence-a bloody glove-near Simpson's house. See William Claiborne, Issue of Racism Emerges at O.J. Simpson Hearing; Admissibility of Detective's Remarks Argued, WASH. POST, Jan. 14, 1995, at A3. The defense introduced evidence that, in the past, this police officer had used racial epithets, including the word "nigger," and had admitted planting evidence in other cases. See William Claiborne \& Lorraine Adams, Ito Recuses Himself on Tapes Ruling; Detective in Simpson Case Disparaged Judge's Wife in Interview, WASH. POST, Aug. 16, 1995, at Al. The response of the prosecution and many commentators was that the defense, in using this evidence to impeach the witness, was "playing the race card," i.e., injecting irrelevant racial issues into the trial. See id. (quoting Marcia Clark, chief prosecutor in Simpson case, as saying that defense was " "playing the race card"); Mary McGrory, Views From the Jury Box, WASH. POST, Oct. 5, 1995, at A2 ("Playing the race card is always unconscionable, but doing it in a double murder trial is a disgrace, even if inept prosecutors have handed it to you in the person of the odious Fuhrman ...."). Many African-Americans, in contrast, may have been persuaded that either the officer's testimony itself or the fact that the prosecution sponsored the testimony of a racist witness created reasonable doubt about Simpson's guilt, even though the prosecution also presented circumstantial evidence from other sources. Therefore, the black jurors' decision to acquit would have been based on a faithful application of the law to the facts; they reasonably would have doubted the government's proof of the defendant's guilt, as incredible as that seemed to many non-blacks (although it was obviously not incredible to the two whites and one Hispanic on the jury, all of whom joined in the unanimous verdict of acquittal). See Paul Butler, O.J. Reckoning: Rage for a New Justice, WASH. POST, Oct. 8, 1995, at C1, C2 (explaining why Simpson verdict probably was based on reasonable doubt as opposed to jury nullification).

In the recent line of cases prohibiting the consideration of race in the exercise of peremptory challenges, the Supreme Court has ignored the different ways in which black and non-black jurors might perceive evidence. See, e.g., Batson v. Kentucky, 476 U.S. 79 (1986). These cases are troubling because the Court exhibits the same willful blindness to the significance of race that the D.C. Circuit exhibited in United States v. Barry, Nos. 90-3149, 90-3150, \& 90-3151, 1990 WL 104925 (D.C. Cir. July 5, 1990), see supra Subsection I.C.I.

I have explained that the liberal critique reflects the view that the criminal justice system is racist because many of its actors are prejudiced, see supra Subsection II.A.1; accordingly, liberal critics are more likely to find racially based reasonable doubt than others, including radical critics, who attribute racial problems in criminal justice mainly to factors other than discrimination by law enforcers.

226. This critique is evidenced, for example, in the view of some blacks that taking property that does not belong to them is a way to speak out against the status quo. See, e.g., Dwight L. Greene, Naughty by Nurture: Black Male Joyriding-Is Everything Gonna Be Alright?, 4 COLUM. J. GENDER \& L. 73, 75, 84-95 (1994) (arguing that, for some young black men, stealing cars for joyrides can be form of social protest). It can also be seen in a question often asked by black people upon hearing about the all-toofamiliar scenario of a poor black person being the victim of a property crime perpetrated by another black person: "Why don't those [black perpetrators] go to [insert the name of the local rich white neighborhood] to commit those crimes? Why do they take from people who don't have anything?" That this question does not seem to be asked in the context of a violent crime (i.e., "Why didn't that black murderer kill a white 
I would encourage nullification here only in extreme cases (i.e., nonviolent theft from the very wealthy) and mainly for political reasons: If the rich cannot rely on criminal law for the protection of their property and the law prevents more direct self-help measures, perhaps they will focus on correcting the conditions that make others want to steal from them. This view may be naive, but arguably no more so than that of the black people who thought that if they refused to ride the bus, they could end legally enforced segregation in the South.

\section{Some Political and Procedural Concerns}

\section{What if White People Start Nullifying Too?}

One concern is that whites will nullify in cases of white-on-black crime. The best response to this concern is that often white people do nullify in those cases. The white jurors who acquitted the police officers who beat up Rodney King are a good example. ${ }^{227}$ There is no reason why my proposal should cause white jurors to acquit white defendants who are guilty of violence against blacks any more frequently. My model assumes that black violence against whites would be punished by black jurors; I hope that white jurors would do the same in cases involving white defendants.

If white jurors were to begin applying my proposal to cases with white defendants, then they, like the black jurors, would be choosing to opt out of the criminal justice system. For pragmatic political purposes, that would be excellent. Attention would then be focused on alternative methods of correcting antisocial conduct much sooner than it would if only African-Americans raised the issue.

person?") strengthens my supposition that it is based on a theory of property rights as opposed to mere racial prejudice.

227. The current Solicitor General Drew Days remarked on such cases while testifying before Congress on Justice Department efforts to prosecute police brutality:

[E]ven in those cases where we had strong evidence, and where we had a right to actually obtain prosecution, we ran into jury nullification. Jurors simply would not convict police officers. And we had to deal with the fact that most of the victims of police misconduct are people who come from the wrong side of the tracks, if you will.... [including] racial minorities.

Police Brutality: Hearings Before the Subcomm. on Civil and Const. Rights of the House Comm. on the Judiciary, 102d Cong., 1st Sess. 172 (1991), quoted in Paul Hoffman, Double Jeopardy Wars: The Case for a Civil Rights "Exception", 41 UCLA L. REV. 649, 668 (1994).

On the question of reasonable doubt in the jurors' minds, there was an important difference between the evidence in the "Rodney King" case (Why is that case known by the name of the victim? Who were the white defendants? Why don't many of us remember their names?) and the Simpson case (which I guess, to be consistent, we should call the "Ronald Goldman and Nicole Simpson" case). The evidence in the "Stacey Koon et al." case included a videotape of the crime, while the evidence in the Simpson case was entirely circumstantial and was tainted by the involvement of a racist police officer. Based on my experience as a prosecutor, I would say that the difference in the evidence in those cases was significant. 


\section{How Do You Control Anarchy?}

Why would a juror who is willing to ignore a law created through the democratic process be inclined to follow my proposal? There is no guarantee that she would. But when we consider that black jurors are already nullifying on the basis of race because they do not want to send another black man to prison, we recognize that these jurors are willing to use their power in a politically conscious manner. Many black people have concerns about their participation in the criminal justice system as jurors and might be willing to engage in some organized political conduct, not unlike the civil disobedience that African-Americans practiced in the South in the 1950s and 1960s. It appears that some black jurors now excuse some conduct-like murder-that they should not excuse. My proposal, however, provides a principled structure for the exercise of the black juror's vote. I am not encouraging anarchy. Instead, I am reminding black jurors of their privilege to serve a higher calling than law: justice. I am suggesting a framework for what justice means in the African-American community.

\section{How Do You Implement the Proposal?}

Because Sparf, as well as the law of many states, prohibits jurors from being instructed about jury nullification in criminal cases, ${ }^{228}$ information about this privilege would have to be communicated to black jurors before they heard such cases. In addition, jurors would need to be familiar with my proposal's framework for analyzing whether nullification is appropriate in a particular case. Disseminating this information should not be difficult. AfricanAmerican culture-through mediums such as church, music (particularly rap songs), black newspapers and magazines, literature, storytelling, film (including music videos), soapbox speeches, and convention gatherings-facilitates intraracial communication. At African-American cultural events, such as concerts or theatrical productions, the audience could be instructed on the proposal, either verbally or through the dissemination of written material; this type of political expression at a cultural event would hardly be unique-voter registration campaigns are often conducted at such events. ${ }^{229}$ The proposal could be the subject of rap songs, which are already popular vehicles for racial critiques, ${ }^{230}$ or of ministers' sermons. ${ }^{231}$

228. See supra note 147 and accompanying text.

229. See, e.g., Geoff Brown, "Hey, Baby, Won't You Be My Dog and I'll Be Your Tree." George Clinton Talks Dirty to Geoff Brown, INDEPENDENT, July 14, 1995, at 11 (stating that black "funk" musician George Clinton encourages voter registration at his concerts).

230. See Kennedy, supra note 83 , at 1258 n.10 (noting advocacy of racial critiques of criminal justice by rap musicians).

231. In a Christian church, the sermon might be based on the book of Isaiah: "The Spirit of the Lord God is upon me; because the Lord hath anointed me to preach good tidings unto the meek; he hath sent 
One can also imagine more direct approaches. For example, advocates of this proposal ${ }^{232}$ might stand outside a courthouse and distribute flyers explaining the proposal to prospective jurors. ${ }^{233}$ During deliberations, those jurors could then explain to other jurors their prerogative-their power-to decide justice rather than simply the facts. Sparf is one Supreme Court decision whose holding is rather easy to circumvent: If the defense attorneys cannot inform the people of their power, the people can inform themselves. And once informed, the people would have a formula for what justice means in the African-American community, rather than having to decide it on an ad hoc basis. ${ }^{234}$

I hope that all African-American jurors will follow my proposal, and I am encouraged by the success of other grass-roots campaigns, like the famous Montgomery bus boycott, aimed at eliminating racial oppression. ${ }^{235}$ I note, however, that even with limited participation by African-Americans, my proposal could have a significant impact. In most American jurisdictions, jury verdicts in criminal cases must be unanimous. One juror could prevent the conviction of a defendant. The prosecution would then have to retry the case, and risk facing another African-American juror with emancipation tendencies. ${ }^{236}$ I hope that there are enough of us out there, fed up with prison

me ... to proclaim liberty to the captives, and the opening of the prison to them that are bound ...." Isaiah 61:1.

232. Such advocates might include members of Families Against Mandatory Minimums (FAMM), a group founded to combat the harsh consequences of mandatory-minimum sentences for certain crimes. See Johnson, supra note 219 , at $2 \mathrm{~A}$ (describing rioting at federal prisons in response to failure of Congress to equalize sentences for powder cocaine and crack cocaine offenses, and noting position of president of FAMM that rioting was predictable based on unfairness of sentencing disparity).

233. Anti-abortion activists have used similar tactics to encourage jury nullification in trials of people who engaged in civil disobedience at abortion and family-planning clinics. In one set of cases, in San Diego, one defendant was the publisher of a local newspaper, and, as the trials began, the paper ran an advertisement informing current and potential jurors that "You Can Legally Acquit Anti-Abortion "Trespassers" Even If They're "guilty."” Alan W. Scheflin \& Jon M. Van Dyke, Merciful Juries: The Resilience of Jury Nullification, 48 WASH. \& LEE L. REV. 165, 180 (1991), quoted in ABRAMSON, supra note 121 , at 57 . The ad stated that the jurors would be told that they were not allowed to nullify, but that it would be "unjust and illegal"' for the judge and prosecutor to deny them that right. Michael Granberry, Abortion Protest Juries Told to Ignore Nullification Ad, L.A. Times (San Diego County ed.), Jan. 27, 1990, at $\mathrm{B} 1$, quoted in ABRAMSON, supra note 121 , at 58.

234. I am aware that, at present, my formula is simply one African-American man's view of what justice means, and I am entirely amenable to a more democratic reshaping of that idea, perhaps by some representative organization of African-Americans. I would not be troubled if my proposal were limited in some way, such as by restricting nullification to cases of drug possession, as opposed to drug distribution.

235. The Montgomery bus boycott was sparked by the arrest of Rosa Parks, who refused to give up her seat on a public bus to a white person, in violation of the Montgomery, Alabama segregation statute. The subsequent boycott of the buses caused significant hardship for its African-American participants, including the loss of employment, physical violence, and the inconvenience of having to walk to work every day for more than a year. See generally Walt Harrington, "A Person Who Wanted To Be Free" (pt. 2), WASH. POST, Oct. 8, 1995, Magazine, at W10, W24 (providing biographical account of Rosa Parks in context of civil rights movement).

236. Prosecutors probably would try to identify jurors likely to nullify through voir dire; if those jurors could be identified, they probably would be excused, through challenges for cause or peremptory challenges. The African-American juror facing this situation would be placed in the difficult position of having to choose between revealing her racial sympathy, and thus surrendering her power, or denying her racial sympathy, and thus committing perjury. Yet the legal and moral case for jury nullification might lead 
as the answer to black desperation and white supremacy, to cause retrial after retrial, until, finally, the United States "retries" its idea of justice.

\section{CONCLUSION}

This Essay's proposal raises other concerns, such as the problem of providing jurors with information relevant to their decision within the restrictive evidentiary confines of a trial. Some of these issues can be resolved through creative lawyering. ${ }^{237}$ Other policy questions are not as easily answered, including the issue of how long (years, decades, centuries?) black jurors would need to pursue racially based jury nullification. I think this concern is related to the issue of the appropriate time span of other raceconscious remedies, including affirmative action. Perhaps, when policymakers acknowledge that race matters in criminal justice, the criminal law can benefit from the successes and failures of race consciousness in other areas of the law. I fear, however, that this day of acknowledgement will be long in coming. Until then, I expect that many black jurors will perceive the necessity of employing the self-help measures prescribed here.

I concede that the justice my proposal achieves is rough because it is as susceptible to human foibles as the jury system. I am sufficiently optimistic to hope that my proposal will be only an intermediate plan, a stopping point between the status quo and real justice. I hope that this Essay will encourage African-Americans to use responsibly the power they already have. To get criminal justice past the middle point, I hope that the Essay will facilitate a dialogue among all Americans in which the significance of race will not be dismissed or feared, but addressed. The most dangerous "forbidden" message is that it is better to ignore the truth than to face it.

the juror to believe that her perjury would be morally justifiable. As a former prosecutor, it is difficult for me to encourage any juror to violate her oath. As an African-American, however, it is also difficult for me to encourage my people to relinquish the greatest power they have against the tyranny of the majority. Ultimately, it must be an individual decision.

For me, the issue of whether a lie under oath is ever justifiable is most clear when I ponder what my reaction would be if I were being considered for a jury that had the power to sentence a defendant to death. The Supreme Court has ruled that people opposed to the death penalty may be challenged by the prosecution from sitting as jurors in capital cases. See Witherspoon v. Illinois, 391 U.S. 510 (1968). I believe with all my heart that capital punishment is morally wrong, and I would have no compunction about lying about this belief during voir dire if my lie could prevent the government from killing a human being.

237. In the Barry case, for example, Barry and his attorney essentially put the government's conduct in setting up the "sting" operation on trial. See Hedges, supra note 19, at A1, B5; McGrory, supra note 19, at A2. Barry himself spoke at various rallies, condernning his trial as being dominated by racism. See id. 
